NBER WORKING PAPER SERIES

\title{
THE WORLDWIDE ECONOMIC IMPACT OF THE REVOLUTIONARY AND NAPOLEONIC WARS
}

\author{
Kevin H. O’Rourke \\ Working Paper 11344 \\ http://www.nber.org/papers/w11344 \\ NATIONAL BUREAU OF ECONOMIC RESEARCH \\ 1050 Massachusetts Avenue \\ Cambridge, MA 02138
}

May 2005

The work for this paper was done while the author was an IRCHSS Government of Ireland Senior Fellow. I am grateful to the Irish Research Council for the Humanities and Social Sciences for their generous research funding. I also gratefully acknowledge research funding under the European Commission's Sixth Framework Programme, Marie Curie Research Training Network contract number MRTN-CT-2004-512439. William Hynes, Patrick Leahy, and Hampus Willfors provided excellent research assistance. I also wish to thank Liam Brunt, François Crouzet, Jean-Pierre Dormois, David Eltis, Stanley Engerman, Javier Cuenca Esteban, Ronald Findlay, Dennis Flynn, Arturo Giraldez, Philip Hoffman, Douglas Irwin, Jan Tore Klovland, Jim Livesey, Leandro Prados, David Richardson, Jean-Laurent Rosenthal, Lennart Schön, Alan Taylor and Jeffrey Williamson for generous help with sources, making available unpublished material, encouragement and advice. Stanley Engerman and François Crouzet most generously provided extensive written comments on earlier drafts. Participants at the OFCE economic history seminar and the NBER DAE 2005 Spring Program Meeting made a number of helpful comments for which I am grateful. Needless to say, the usual disclaimer applies. The views expressed herein are those of the author(s) and do not necessarily reflect the views of the National Bureau of Economic Research.

(C2005 by Kevin H. O'Rourke. All rights reserved. Short sections of text, not to exceed two paragraphs, may be quoted without explicit permission provided that full credit, including $\odot$ notice, is given to the source. 
The Worldwide Economic Impact of the Revolutionary and Napoleonic Wars

Kevin H. O'Rourke

NBER Working Paper No. 11344

May 2005

JEL No. F1, N7

\begin{abstract}
The paper provides a comparative history of the economic impact of the Revolutionary and Napoleonic Wars. By focussing on the relative price evidence, it is possible to show that the conflict had major economic effects around the world. Britain's control of the seas meant that it was much less affected than other nations, such as France and the United States. Explicit welfare calculations are provided for four countries, Britain, France, Sweden and the United States. Welfare losses were largest in the US, where they were of the order of 5-6\% per annum; by contrast, they lay between 34\% per annum in France, and between 1.7-1.8\% per annum in Britain. On the other hand, the conflict helped pave the way for the more liberal international economic environment of the long 19th century.
\end{abstract}

Kevin H. O'Rourke

Department of Economics

Trinity College

Dublin 2

Ireland

and NBER

kevin.orourke@tcd.ie 


\section{Section 1. Introduction}

The years between 1793 and 1815 saw an unusually bloody, lengthy and widespread conflict between Great Britain and France, which widened to include many of the other leading powers of the day. The period is also notable for its economic warfare, which involved not only the belligerents, but several (at least initially) neutral countries, notably the young United States. This paper offers a comparative, quantitative assessment of the economic impact of the conflict. While data availability dictates that the paper's focus be on comparatively well-documented countries, such as Britain, France and the US, the paper will attempt to range more widely, and bring together evidence concerning the impact of the wars not just on Europe and North America, but on Latin America, Asia and Africa as well. The paper has three main conclusions. First, the wars of 1793-1815 had a powerful, worldwide economic impact. Second, they imposed large welfare costs, both on participating nations and on neutrals. Third, Britain was less severely damaged by the conflict than its main military and economic rivals.

Several scholars have already explored this episode, some in considerable detail. Eli Heckscher's (1922) great book on Napoleon's Continental Blockade remains the starting point for any serious exploration of the subject, ${ }^{1}$ while François Crouzet's (1987) exhaustive study is the definitive work on the impact of the Blockade on Britain. As will be seen, the two authors differ in their assessment of the Blockade's effectiveness: Heckscher emphasises the smuggling and corruption which undermined Napoleon's attempts to prevent British goods from entering the Continent, while Crouzet argues that the Blockade did damage British industry, at least in the periods when it was effectively enforced. However, neither author

\footnotetext{
${ }^{1}$ For a recent insightful review of this work, see Crouzet (2003).
} 
attempts to provide an explicit welfare assessment of the episode. A separate literature explores the effects of the Blockade on the European Continent: Crouzet (1964) provides a classic (and succinct) overview, while Ellis (1981) focusses on the impact of the Blockade on one industrialising region, Alsace. Meanwhile, Frankel (1982) and Irwin (2001) have written on Jefferson's Embargo, which cut off trade between the United States and Europe for over a year. This paper follows Frankel in stressing that relative prices provide a good measure of such a policy's effectiveness; while it follows Irwin in attempting to explicitly measure the welfare effects of war-related trade disruption. Most recently, Davis and Engerman (forthcoming) provide an extremely useful overview of Anglo-French and Anglo-American trade rivalry during the period, within the context of a broader study of blockades, but without providing estimates of welfare loss.

The above works all focus on particular trade disputes which occurred within the context of more than two decades of war. This paper is wider in scope, in that it looks at the trade and welfare consequences of the war in general, with a particular emphasis on the 180714 period; by and large, it does not attempt to untangle the separate effects of Britain's maritime blockade of France, France's counter-blockade of Britain, the economic and military disputes between Britain and the United States, and so on. Rather, it looks at the combined effects of these several shocks to the system, which were all ultimately due to the war.

The paper is also related to a more technical literature on the impact of war on trade. This literature, of which Glick and Taylor (2005) is the most recent example, typically uses the volume of trade as the dependent variable, and employs gravity models to see how wars affected it. Glick and Taylor go further, by using separately generated (by Frankel and Romer 1999) estimates of the relationship between trade and welfare to calculate the welfare effects 
of war within the context of a panel of countries between 1870 and 1997 . Their results suggest that the welfare effects of war-related trade disruption have been large: during World War I, for example, they were equivalent to a permanent flow loss of $2.74 \%$ of GDP for belligerents, and $2.09 \%$ of GDP for neutrals. This paper also stresses the impact of war on neutrals, but differs from Glick and Taylor's work in that relative prices are the basis for my welfare calculations, rather than trade volumes. ${ }^{2}$ It also differs from theirs in that it generates welfare estimates country by country, rather than using coefficients which are common across a group of countries. As will be seen, this is an important difference, since not all countries were the same, and war affected their trade, and welfare, in very different ways. ${ }^{3}$

The paper begins with a brief summary of the conflict, and the ways in which it disrupted trade. Section 3 then looks at what is known about the behaviour of trade volumes during the period, stressing the uncertain nature of some of the evidence. Section 4 shifts the focus onto the relative prices of importable and exportable goods in several countries and continents. Section 5 attempts to measure the welfare effects of trade disruption in four countries: Britain, France, the United States and Sweden. Section 6 concludes with a brief discussion of some of the longer-run implications of the conflict.

${ }^{2}$ This stress on relative prices is largely dictated by considerations of data quality, and mirrors the strategy adopted by O'Rourke and Williamson (2002a).

${ }^{3}$ The paper is also somewhat related to the literature on sanctions, epitomised by Hufbauer et al. (1990), who find that roughly a third of all sanctions episodes in the $20^{\text {th }}$ century have been successful. Not surprisingly, success is related to the relative costs imposed upon the sender and the target of the sanctions (Eaton and Engers 1999), and these relative costs are one of the principal foci of the present paper. 


\section{Section 2. The Twenty-Three Years War ${ }^{4}$}

The $18^{\text {th }}$ century saw the growth and maturation of a well-defined global economy encompassing not just the traditional inter-continental trade between Europe and Asia, but a more dynamic and economically important Atlantic trade involving Africa and the Americas as well. The deep-rooted mercantilism of the period made the system vulnerable to international conflicts, however, as European nations competed for the rents associated (or thought to be associated) with the control of colonies and trade. Mercantilist wars periodically impeded international trade; to take just two examples, Euro-Asian commodity price gaps rose during the first and second Anglo-Dutch Wars (1652-54 and 1665-67) and the Seven Years War (1756-63) (O’Rourke and Williamson 2002b, Figure 4, p. 33); while prices of imported goods such as paper and pepper rose substantially in Peru during the War of the Spanish Succession (1701-13), and the War of Jenkin's Ear between Spain and Britain (173941) (Brown 1990, pp. 183-5).

But this constant warfare would ultimately have more far-reaching, systemic effects as well. Christopher Bayly (2004) has recently pointed out that conflicts such as the Seven Years War, which involved not just Britain and France, but also Austria, Russia, Saxony, Sweden, Spain, Hanover and Prussia, and in which fighting took place in Europe, North America and India, placed great fiscal strains on European states; these in turn gave rise to serious internal political problems. For example, in Britain the House of Commons refused to vote higher land taxes in 1767, while the increased power of business there made it impossible for government to default on its debts, as had happened in 1672 under Charles II. Politically, it seemed much easier to transfer the tax burden to the colonies, for example by collecting

\footnotetext{
${ }^{4}$ This section draws heavily on Findlay and O'Rourke (2003, pp. 32-35).
} 
stamp duty (McCusker 1996, pp. 360-1). Thus it was that British attempts to raise taxation in North America, as well as the stationing of a large royal army there, provided a spark for the American Revolution. In turn, French fiscal problems, aggravated by France's support for the American colonists, led to attempted reforms in France, and helped produce the French Revolution of 1789.

A series of mercantilist wars were therefore followed by a larger conflagration, into which an additional ideological dimension had now been injected. In 1792, France declared war on Austria and Prussia; and on February $1^{\text {st }}, 1793$, the French National Convention declared war on Great Britain. The ensuing period of warfare between the two countries, which lasted almost uninterrupted until 1815 (there was a brief interlude of peace which lasted from the Peace of Amiens in March 1802 until the renewal of war in May 1803, and another during 1814-15), had profound and long-lasting effects on international trade worldwide.

Within a month, the Convention had prohibited the importation of large classes of British goods, and in October it banned all British manufactured goods; meanwhile, the British side adopted a policy of blockading the coast of France. As Eli Heckscher's classic account emphasizes (Heckscher 1922), each side was motivated by a mercantilist desire to prevent the other exporting, and thus acquiring precious metals, rather than by a desire to prevent the enemy from importing food or other goods which might be useful to the war effort. ${ }^{5}$ There was also the hope that by preventing exports, the enemy's economy could be damaged, causing unemployment and political unrest. This gave the blockades of the 1790s, as well as the later Continental Blockade, a distinctly $18^{\text {th }}$ century flavour; thus, in 1809 and

\footnotetext{
${ }^{5}$ The exception being that food exports were occasionally banned when domestic food supplies were scarce.
} 
1810, when Britain was suffering from poor harvests, but France had food in abundance, Napoleon authorized food exports to its enemy. Such a policy stance, based on the hope that one's opponent could be brought to its knees by supplying it with food in return for gold, relied on the assumption that Britain needed trade surpluses to finance its war effort on the Continent; it ignored the possibility that the war effort could be financed via capital flows (Neal 1991), and invites counterfactual speculation as to what would have happened had Napoleon understood correctly that imports are desirable, and attempted to starve out the British. $^{6}$

Both the French and the British took measures against neutral shipping which transported enemy goods, but the bilateral trade dispute took on a multilateral nature in December 1800, when Russia, Denmark, Sweden and Prussia formed the League of Armed Neutrality (which succeeded a similar arrangement between the two Scandinavian countries in 1794), agreeing to provide naval protection for their merchant shipping. This arrangement came to an end in 1801, but not before the British had announced a blockade on trade with the League (bar Prussia), and physically attacked Copenhagen. Trade disruption was to become far more widespread in the aftermath of Napoleon's military victories over Austria in 1805 and Prussia in 1806. In November 1806, his Berlin Decree declared that the British Isles were under blockade (somewhat fancifully, since Britain controlled the seas), that all trade in British goods were prohibited, and that all vessels coming directly from Britain or her colonies were to be turned away from French ports. More importantly, Napoleon began applying these restrictions, not just in France, but in vassal states such as Spain, Naples and

${ }^{6}$ Rose (1902); Heckscher (1922); Olson (1963); Crouzet (1987, pp. 564-571), Crouzet (2003). In fact, Napoleon was also motivated by the desire to help French farmers, who were struggling with the effects of a bumper crop; and by the need for government revenue. 
Holland. His forces defeated those of Russia in 1807; the ensuing Treaty of Tilsit implied that not just Russia, but Denmark and Portugal, joined the blockade (the former voluntarily, the latter as a result of a French invasion), as did Prussia; the result was that virtually the entire Continent was now in a state of 'self-blockade' against the exports of Britain, the overwhelmingly dominant industrial power of the time. ${ }^{7}$

Nor did matters end there. In November 1807 the British declared that neutral ships could be seized if found to be carrying goods from enemy colonies to their mother countries, even if they first transited via neutral ports; on the other hand neutral ships could still carry goods from enemy colonies to their own home ports, or from enemy colonies to British ports, or from their own home ports to British ports, or from British ports to enemy ports. The practical effect of this was that neutrals would have to put into British ports if they wanted to ship goods from, say, French colonies (or indeed, from their own country) to France. Napoleon retaliated by declaring that any neutral ship putting into a British port was fair prize, and could be seized. Faced with a situation where neutral ships carrying goods to the Continent were now subject to seizure from either one side or the other, the young U.S. government closed its ports in December to belligerent shipping and forbade its own ships to leave these ports. This Embargo Act was repealed in 1809, and replaced with a nonIntercourse Act which only banned trade with Britain and France (and which was clearly difficult to enforce, once ships had been given leave to sail to Europe). Nonetheless, for fourteen months the United States found itself in a state of virtual autarky (Irwin 2001).

Russia broke with France in 1810, by 1813 Napoleon was in retreat and the Continental Blockade was unravelling in several directions, and the Blockade legislation was

${ }^{7}$ The only Continental country to hold out was Sweden, which was eventually forced to join the blockade in 1810 . 
finally repealed following Napoleon's abdication in 1814, having effectively collapsed in the summer of 1813. On the other hand, in 1812 continuing friction over trade-related issues led to the United States declaring war on Britain. There followed British attempts to blockade the US coastline, attempts which were greatly helped by victory over Napoleon in 1814, which allowed the Royal Navy to redeploy its forces there. The day after the peace treaty between France and Britain was signed, Britain ordered that the entire US coastline be blockaded. The war between Britain and its former colony, and the ensuing damage to trade, was to last for the rest of the year.

The period was also marked by war and revolution in the Carribean and Latin America. In 1791, slaves on the French sugar colony of Saint Domingue rose against their masters, and after resisting British and French invasions, Haiti became an independent republic in 1804. Naval warfare between Spain and Britain (1796-1802 and 1804-8) seriously disrupted Latin American trade; this was followed by a series of revolutions in the following decade, following Napoleon's invasion and occupation of Iberia in 1808. By the $1820 \mathrm{~s}$ independent republics (or, the case of Brazil, an independent Empire) had been established across the continent.

For over 20 years leading governments had acted so as to severely disrupt international trade, and under the Continental System that disruption had been widespread and rather extreme. The question now arises as to what were the economic consequences of this disruption, in both the short and longer run.

\section{Section 3. War and the volume of trade}

Did measures such as the Continental Blockade and Britain's naval blockade of enemy ports seriously impede the integration of international commodity markets, or were 
they so undermined by smuggling, corruption and fiscally-motivated legal exceptions to the general protectionist rule as to have had no significant effect? There is certainly a strand in the literature which holds the latter view: for example, Heckscher (1922) emphasises the normality of smuggling, which was universally acknowledged at the time. He cites no less a figure than Napoleon, in a letter to King Louis of Holland dated April 3, 1808, as saying that "If you need to sell your gin, the English need to buy it. Settle the points where the English smugglers are to come and fetch it, and make them pay in money but never in commodities" (p. 192). While this seems more an extension of Napoleon's generally mercantilist policies than anything else, Heckscher stressed the "hopelessness of enforcing obedience to the blockade decrees" (pp. 366-7) and concluded that the policy merely served to transfer foregone customs revenue from the French state to smugglers and corrupt officials (p. 197). Similarly, the qualitative literature contains many references to smuggling which undercut the effectiveness of the US Embargo; Jefferson himself concluded that "this embargo law is certainly the most embarrassing we ever had to execute. I did not expect a crop of so sudden and rank growth of fraud, and open opposition by force, could have grown up within the United States" (cited in Davis and Engerman, forthcoming, Chapter 3).

By contrast, François Crouzet (1987), while not denying that corrupt French officials did undermine the effectiveness of the Continental Blockade, nevertheless maintains that the blockade was effective from mid-1807 to mid-1808, and again from spring 1810 until the winter of 1812; while Frankel (1982) has persuasively argued that the Jefferson Embargo successfully impeded Anglo-American trade during 1808. Only quantitative evidence can resolve an issue such as this.

Figure 1 shows estimates of the volume of trade between 1780 and 1830 for the two main belligerents, Britain and France, as well as for two neutrals, Sweden and the United 
States. The shaded area in the graph refers to the period between 1807, the beginning of the Continental Blockade and the Jefferson Embargo, and 1814, when wartime disruption between Britain and the United States was at its peak. On the face of it, the effects on Britain seem to have been relatively minor. Imports seem to have been reduced between 1811 and 1814 (although this is relative to a peak in 1810), but apart from a dip in 1811 exports seem to have been close to trend throughout the period. By contrast, French imports were seriously reduced throughout the war, while her exports were lower during 1808-11 than in 1806 and 1807. ${ }^{8}$ There is little obvious impact on Swedish trade volumes; but U.S. exports and imports declined substantially after 1808 , and collapsed in 1814 , when trade volumes were only around $10 \%$ of their 1820 levels.

An alternative way of measuring the impact of wartime blockades on trade volumes, given the existence of strong upward trends in some of these time series, is to regress the log of the series on time, time squared, and a blockade dummy variable taking the value one for the years 1807-14 and zero otherwise. The percentage impact of the blockade on trade (relative to a no-blockade counterfactual) is then given by $100 *\left(\mathrm{e}^{\delta}-1\right)$ where $\delta$ is the coefficient on the blockade dummy variable. Table 1 gives the percentage changes in trade volumes for these four countries during 1807-14 relative to the no-blockade counterfactual; entries in bold type correspond to equations in which the coefficient on the blockade dummy variable was statistically significant. As can be seen, British trade was essentially unaffected by the blockades; on the other hand, French and American imports were halved during the

${ }^{8}$ According to Cuenca Esteban (2004), French imports (in constant 1787-9 prices) fell from an annual average of $£ 21.5$ million in $1787-9$ to just $£ 9.2$ million during the war (that is, 1797-1812 and 1814-15); while Britain’s imports rose during the same period from $£ 27.1$ million to $£ 42.1$ million (Table 2.1, pp. 38-9). Exports of French domestic products rose by some $17 \%$, from $£ 10.6$ million to $£ 12.5$ million; while British exports rose by $92 \%$, from $£ 17.8$ million to $£ 32.3$ million (Table 2.3 , pp. 42-3). 
period, while US exports were reduced by a third. The blockades do not seem to have reduced Swedish trade volumes at all, according to these measures. The message from the table is that Britain's opponents appear to have done worse than Britain herself; on the other hand, the fact that the French and American declines in trade volumes appear to be greater on the import side than on the export side is consistent with (if unlikely to be entirely explained by) the under-reporting of trade due to smuggling (which, one assumes, would have posed a greater problem for compiling accurate import statistics than for export statistics, in cases where governments were mainly concerned with reducing their opponents' exports).

The trade effects of the wars were not limited to Europe and North America. According to Salvatore and Newland (2003, Figure 2.1, p. 21), Argentinian per capita exports collapsed by two thirds between 1810 and 1812, before recovering their 1810 level in 1814 and surpassing it thereafter. The Spanish blockade of Buenos Aires was an Argentine-specific factor in this case, but Latin American trade more broadly was severely disrupted during the conflict (Bulmer-Thomas 2003, p. 19). Not only that; an inability to export, and later the struggle for Latin American independence, severely hit the continent's output of silver, one of its major export commodities. According to the available data, ${ }^{9}$ almost a century of continual expansion was replaced immediately after the onset of the wars by wildly fluctuating output around an essentially flat trend, which then started declining; according to Dermigny (1964, p. 1206), Mexican silver output, which had averaged more than 20 million piastres p.a. between 1792 and 1806, fell to an annual average of 16.4 million between 1807 and 1813 , 11.3 million between 1814 and 1820, and just 8.8 million between 1821 and 1827 . The result was that worldwide silver production, which had averaged more than 28 million ounces

\footnotetext{
${ }^{9}$ See the data given at the Latin American Economic History Data Bank, http://mansell.stucen.gatech.edu/rlg7/latamdata/index.html.
} 
between 1781 and 1810 , fell to 17.4 million ounces in the following decade, and 14.8 million during the 1820s (Vilar 1976, p. 331). In turn, this decline in Latin American silver output had consequences around the world. To take one example, British silver shipments to India and China declined dramatically, with a much greater proportion of Britain's payments to those countries in exchange for their exports taking the form of merchandise than had been the case during the $18^{\text {th }}$ century (Dermigny 1964, pp. 1209-10).

Figure 2 shows that exports from Africa were also seriously disrupted by the war: it gives 5-yearly totals of African slave exports from the 1670s until the final end of the trade in the 1860 s. The shaded area represents the period from 1791 to 1815 : exports during 1811-15 were less than half of what they had been in the late 1780s. Of course, warfare was not the only factor disrupting the slave trade: in 1808 the British government abolished the slave trade between Africa and British colonies, the same year that saw the abolition of the United States slave trade, and five years after the Danish decision to end her own slave trade in 1803 (Engerman 1981, pp. 4-5). The Dutch abolished their slave trade in 1815, and formally the French trade was ended the following year (although illegal trade continued for several decades). And yet wartime disruption to shipping, as well as the slave revolt on Saint Domingue, must have played a role as well, since exports were already falling in the $1790 \mathrm{~s}$, before abolition; and since once the war had ended, slave exports resumed, before finally collapsing after 1850 or so. ${ }^{10}$

The case of South East Asia is perhaps the exception that proves the rule. Bulbeck et al. (1998, pp. 12-13) document South East Asian trade in four key regional exports, cloves, pepper, sugar and coffee, and find that the 1780s marked a (positive) turning point for South

${ }^{10}$ Indeed, previous $18^{\text {th }}$ century wars had led to the complete cessation of the French slave trade. I am indebted to Francois Crouzet for this point. 
East Asian exports, for a region-specific reason: as will be seen below, the wars led to the end of the colonial trade monopolies, in the long run boosting export supply. Thus, export growth averaged an impressive $4.6 \%$ p.a. during 1780-1829 (p. 15), which was by far superior to the rates achieved previously. On the other hand, trade during the wars was unstable, owing to the disruption of shipping and the French occupation of the Netherlands in 1795: export growth in real terms fell to a mere $0.1 \%$ p.a. in the $1810 \mathrm{~s}$, before increasing to $11 \%$ p.a. in the $1820 \mathrm{~s}$. Javanese sugar barely reached Europe during 1790-1816, while the same was true for the island's coffee exports after 1794 (ibid., pp. 118, 147). However, while exports to Europe declined during the wars, Chinese and, especially, American ships could now buy spices directly in South East Asia, and ship them to their home markets; with sugar and coffee production in Saint Domingue disrupted by the slave rebellion there, there was an abundant demand for the region's output (ibid.).

Overall, it appears that war had a negative impact on trade volumes, but the evidence is not as definitive as one would like, given the problems with the available trade statistics, and the omnipresent possibility that smuggling was in fact quantitatively significant, as Heckscher claimed. Fortunately, there is another way of measuring trade disintegration, and that is to look at the price evidence. If blockades had an impact on trade, then the relative prices of importables should have increased in the affected countries; the relative price of exportables should have declined; the terms of trade should have worsened; and price gaps between export and import markets for particular commodities should have increased. Since there is abundant and high-quality price evidence available for a number of countries during this period, largely thanks to the efforts of the International Scientific Committee on Price History of the 1930s and 1940s (see Cole and Crandall 1964) it makes sense to explore this evidence and see what it reveals. 


\section{Section 4. Relative price evidence}

Figure 3 explores the impact of war on the relative prices of importables in Britain. ${ }^{11}$ Six goods are chosen, two representing imports from Europe, two from Asia, and two from the New World. The European commodities chosen are wheat, which as the leading industrial nation Britain was already importing in the late $18^{\text {th }}$ century, from neighbouring Ireland but also from Northern Europe; and timber, another crucial import which at the end of the $18^{\text {th }}$ century still came predominantly from Northern Europe. Pepper and green tea are chosen as representative imports from Asia; while sugar and raw cotton are chosen as representative imports from the New World. Together, corn, timber, tea, spices, sugar and raw cotton accounted for almost two-fifths of total British imports in 1784-6 (Davis 1979, pp. 110-11). The prices of all six commodities are expressed relative to the price of textiles, which accounted for $45 \%$ of British exports during the same period (ibid., p. 94).

The first graph in Figure 3 concerns the relative price of wheat. According to Thomas Tooke, it cost between 30 and 50 shillings per quarter to ship wheat from the Baltic to Britain in 1810 , as compared with 4s/6d in 1837 , while Glenn Hueckel has estimated that wartime freight, insurance and licence costs accounted for between $25 \%$ and $40 \%$ of British wheat prices in 1812 (Hueckel 1973, p. 369). It would thus be surprising if the relative price of wheat did not rise during the war, and Figure 3 confirms that indeed it did. The relative price of wheat was $57 \%$ higher during the war years (1793-1815) than in the 13 years previously, and it was $47 \%$ higher than during the succeeding 15 years. ${ }^{12}$ Comparing the Blockade period

\footnotetext{
${ }^{11}$ In this and subsequent figures, all relative prices are indexed on 1820=100 (unless otherwise stated).

12 This compares with Hueckel's estimate that over the period 1790-1815, wartime disruption raised the relative price of agricultural commodities in Britain by $28 \%$ (Hueckel 1973, p. 389).
} 
(1807-12, the shaded area in Figure 3), the effect was greater still: relative wheat prices increased $77 \%$ relative to their pre-war average, and $66 \%$ relative to their post-war average.

The relative price of lumber seems also to have profoundly affected by war, although in this case it is admittedly difficult to separate out the effects of trade disruption (which would have lowered British supplies) from the increased naval demand for lumber which the war gave rise to, and which would have led to its relative price increasing even if free trade had been maintained throughout the conflict. As can be seen from the graph, the relative price of lumber peaked during the Continental Blockade period, suggesting that demand-side factors were not the only ones at work, and that trade disruption mattered also. Indeed, Gayer et al. (1953), from whom the timber prices were extracted, were forced to use prices for Yellow American timber after 1808, whereas they had previously used quotations for Memel fir, since "(i)n 1808 the virtual closing off of the Baltic forced British importers to shift rapidly to the American sources of supply. Memel timber in that year was virtually unavailable, its price was astronomically high" (p. 851). Average wartime relative prices were $61 \%$ higher than prices during 1816-20; the relative price of lumber during 1807-12 was $121 \%$ higher than during 1816-20.

It seems clear that war impeded Britain's ability to import goods from Continental Europe, and raised British relative prices of 'temperate zone' agricultural commodities. But what of Britain's overseas trade with Asia and the Americas? Here, the picture is somewhat more nuanced, as would be expected given the fact that Britain was dominant at sea. Take the relative price of sugar, for example. Figure 3 shows that the relative price of sugar was indeed much higher during the war than either before ( $43 \%$ higher) or after ( $66 \%$ higher). However, the relative price of sugar had already been rising prior to 1793 (since 1789, in fact, perhaps due to the influence of the French Revolution on Haitian sugar supplies). Not surprisingly, the 
years of the most intense blockade (1807-12) did not have any particular impact on the relative price of a good imported in the main from the Caribbean and Latin America, rather than Continental Europe. As for raw cotton, its relative price did increase in 1808 and 1809, as a result of the US Embargo, as well as in 1814, but Figure 3 makes it clear that these increases were not out of the ordinary, and have to be set against a trend which was steadily favourable as far as Britain's cotton producers were concerned. Relative cotton prices were indeed lower after the war than during it, but the figure suggests that it would be difficult to attribute this fact to the cessation of hostilities alone.

On the other hand, there is clearer evidence of war-time increases in the relative prices of Asian imports. The relative price of tea was $16 \%$ higher during than after the wars (and note also the very substantial spike in 1780-84, coinciding with the Fourth Anglo-Dutch War). As for the relative price of pepper, it was $53 \%$ higher during the peak of the wartime trade disruption (1807-12) than before the war, and 44\% higher than after, reflecting war-time increases in freight and insurance rates. However, there were also pronounced spikes in this relative price both before $(1784,1789)$ and after $(1824-5)$ the war. While the two earlier spikes can plausibly related to conflict or fears of conflict (the end of the Anglo-Dutch war, and the French Revolution), it is less clear what was driving the latter one.

To summarize: these annual price data suggest a pronounced wartime effect on British imports from Europe, and a less pronounced (if still sizable) effect on imports from Asia and the Caribbean/Latin America. Given that the French were able to influence trade between Britain and large areas of the Continent, which were under their control, but had no power whatsoever to influence Britain's overseas trade, this makes sense. What about other countries participating in the conflict?

Figure 4 looks at relative prices in France, but only from 1798 onwards (which is 
when data become available in the standard source for the period, Chabert 1945). This means that war-time prices can only be compared with post-war prices. As can be seen from the figure, the key British export to the Continent, textiles, was a lot more expensive relative to wheat during the war than afterwards: prices during $1798-1815$ were $77 \%$ higher than during 1816-30. While there was a peak in the relative price during the Continental Blockade period, it does not stand out from similar, earlier peaks, although relative import prices did fall sharply and permanently in 1812-13. War, rather than the blockade itself, seems to have had an important impact on French relative prices in this instance. The situation is different as regards the other major industrial commodity of the early Industrial Revolution, iron: its relative price rose substantially during the Continental Blockade (to a level $41 \%$ higher than its postwar average) but was not higher on average during the war as a whole than afterwards. Iron (as opposed to hardware and other iron products) was not smuggled at all, and it may be that this explains the greater effect of the Blockade per se on iron prices; but this is speculation. The Blockade also appears to have had an important effect in making overseas imports, such as sugar, raw cotton, pepper and coffee, scarcer within France (and indeed this effect is much more clearly discernible than for the European industrial commodities just mentioned): the peaks in the prices of these four commodities relative to the major European exportable (textiles) are very pronounced, with the relative prices during 1807-12 exceeding average postwar levels by 53\%, 124\%, 39\% and 50\% respectively. Another noteworthy feature of the figure, which reinforces the impression that war and blockades did have an important effect on relative prices, is the decline in the relative price of importables coinciding with the Peace of Amiens of 1802-3.

The available price evidence also suggests that the relative prices of overseas importables rose considerably in the Netherlands during the wars, and especially during the 
period of the Continental Blockade (Figure 5). Indeed, the impact of war on relative prices in this maritime nation was more dramatic than in either Britain or France. Relative to textiles prices, sugar was an astonishing 577\% dearer during 1807-12 than it had been before the war, and $277 \%$ dearer than its post-war average. The equivalent figures for raw cotton are $39 \%$ and $90 \%$; those for pepper are $167 \%$ and $161 \%$ respectively. In the case of trade between the Netherlands and Asia, there exists information on intercontinental price gaps for a number of commodities (Bulbeck et al. 1998). Clove prices had been 15.7 times higher in Amsterdam than in South East Asia in the 1760s and the 1770s; the margin declined in the 1800s to 6.5, presumably due to the ending of the VOC monopoly, of which more later. However, it increased again to 8.9 in the $1810 \mathrm{~s}$, reflecting wartime blockades, before collapsing to 1.9 in the 1820 s, and just 1.2 in the 1830 s (ibid., p. 59). Something similar happened in the case of pepper: Euro-Asian price spreads which had been in the 4-5 range in the mid-1700s rose to 6 in the 1780 s, and 9.3 in the 1790 s. There then followed the same pattern of declining spreads in the 1800 s (to 3.8), a rise in the 1810 s (to 5.0), followed by steady decline once the war had ended.

Figure 6 shows the impact of the war on relative prices in Germany. As can be seen, there were spikes in 1810-11 in the prices of European industrial goods (cotton yarn and iron) relative to rye, although these were not particularly noteworthy in the context of longer run trends. As with France, the real impact of the war, and in particular of the blockade period, was to increase the relative prices of non-European imports; and as in the case of the Netherlands, these increases were dramatic. Relative to the price of cotton yarn, the price of sugar was $190 \%$ higher during $1807-12$ than after the war; the relative price of raw cotton was $169 \%$ higher; the relative price of coffee was $197 \%$ higher; and the relative price of tobacco was $121 \%$ higher. 
Nor were the effects of war limited to those countries which were actually involved in it. Sweden had remained outside the Continental System for longer than any other Continental power, only joining it under compulsion in January 1810. According to Heckscher, countries such as Sweden, which had "unhampered supply from Great Britain," found themselves facing "a kind of hypertrophy of imports" as British supplies were diverted from their normal outlets: the result was an improvement in the terms of trade, rather than a deterioration, and a consequent increase in welfare (Heckscher 1922, pp. 264-5). In fact, Figure 7 shows that this happy outcome did not arise. Bar iron was the dominant Swedish export towards the end of the $18^{\text {th }}$ century; Sweden imported colonial goods, as well as grain (especially rye), textiles, and raw materials. The figure shows that prices of textiles and grains, relative to bar iron, shot up during the period of the Continental Blockade. While relative import prices rose sharply in 1810 , the year Sweden joined the Blockade, they did not decline during 1808 and 1809, as would have been the case under Heckscher's hypothesis. The relative price of textiles was $118 \%$ higher during 1807-12 than it was before the wars, and $70 \%$ higher than the post-war average; the figures for rye were $67 \%$ and $77 \%$ respectively; and the figures for wheat were $75 \%$ and $94 \%$ respectively. In the case of all three commodities, their relative prices collapsed once the war was over.

It seems as though the wars of 1793-1815 had important relative price effects in both belligerent powers and neutral countries, despite the undoubted existence of smuggling. Nor was the impact of the wars limited to Europe. According to Jeffrey Frankel (1982), in 1807 the Liverpool price of cotton was $27.5 \%$ higher than the Charleston price; but in the final two months of the embargo the Liverpool price was $293.3 \%$ higher than the Charleston price (Frankel 1982, pp. 307-8). Using prices for a number of key agricultural and industrial commodities, Frankel found that the British terms of trade deteriorated by between $41.9 \%$ and 
$49.7 \%$ during the dispute, while the US terms of trade deteriorated by between $31.6 \%$ and 32.7\% (Frankel 1982, p. 304). Figure 8 confirms that war and embargoes did seriously hamper trans-Atlantic trade, smuggling notwithstanding: the relative price of goods imported from Europe, such as textiles and wine, increased significantly in the US during the years of the Embargo and its aftermath (which culminated in the War of 1812 opposing Britain and the US). Relative to the price of raw cotton, textiles prices were $51.4 \%$ higher during $1807-14$ (the shaded area in the graph) than they were on average post-war, while wine prices were $52.4 \%$ higher. Indeed, compared with the immediate post-war (1816-20) era the effects seem even larger: textiles prices were $110.2 \%$ higher during $1807-14$, and wine prices were $104.1 \%$ higher. A key finding of Figure 8 (consistent with the evidence in Figure 1) is that the most serious disruption to US trade with Europe occurred in 1814, rather than during the Embargo, despite the attention that has been lavished on the earlier episode.

The war also severely affected Latin American markets. Figure 9 shows the price of two key Peruvian imports from Europe, linen and paper, expressed in terms of silver (the key Peruvian export). The paper prices come from different locations, but all the graphs tell a similar story: the relative price of imports rose considerably during the wars. Silver paper prices during 1807-12 (the shaded area in the graph) exceeded their pre-war averages by between $88.7 \%$ and $150 \%$ in these three cities (Lima, Arequipa and Potosí), and they exceeded their 1816-20 levels by between 70.6 and 140\%. Silver prices of Rouen linen in Arequipa during $1807-12$ exceeded their pre-war averages by $68.4 \%$, and they exceeded their 1816-20 average by $167 \%$. War also affected relative prices in Argentina: according to Newland (1998, p. 413) the end of the Napoleonic Wars led to a decline in freight and insurance costs, and a convergence of local on international prices.

Lovejoy and Richardson (1995) provide data on slave prices deflated by the cost of 
imported trade goods, both in West Africa, where British slaving had been heavily concentrated, and further south, in Angola. If their prewar (1788-92) level is taken to equal 100, real West African slave prices stood at 91.6 during 1793-7, 122 during 1798-1802, 132.5 during $1803-7$, but only 74.3 during $1808-14$, and 40.3 during $1815-20$. The prices then recovered, consistent with the evidence in Figure 2 of a recovering slave trade, to 57.6 in the early 1820 s, and 90.1 in the late 1820 s. The timing of the price decline suggests strongly that the British and US abolition of the slave trade was the most important force driving it, an impression strengthened by the evidence that Angolan slave prices were stable after 1808 (Table 3, p. 113); on the other hand, the post-war recovery in slave prices suggests an independent effect for the war as well.

Once again, South East Asia is in some ways the exception that proves the rule. Elsewhere, it seems to have been true that the relative price of imports rose during the wars, and that the relative price of exports fell. While I do not have South East Asian prices of imported goods spanning the pre-war and post-war periods, I do have silver prices for a variety of exported goods. Table 2 gives average decadal silver prices for three exported commodities, cloves, pepper and coffee. The data on coffee prices exhibit similar behaviour to that experienced in other regions of the world, with export prices below their pre-war levels in the 1800 s and to a lesser extent the 1810 s, before rising in the 1820 s. Cloves and pepper reveal a different pattern, however. If the mean price for the 1770 s is taken to be 100 , clove prices averaged 131.6 during the $1801-1820$ period, while pepper prices also rose, to 153.4 during the $1800 \mathrm{~s}$, and 134.4 during the $1810 \mathrm{~s}$. The fact that relative export prices rose during this period, rather than falling, of course reflects the ending of the VOC monopsony mentioned earlier; the difference between this atypical behaviour and the experience of coffee prices can presumably be explained by the fact that while the international cloves and pepper 
trade had been largely controlled by European trading monopolies, coffee was also produced in the Western hemisphere, and its world price was thus not affected by the decline and fall of the VOC. Even in the South East Asian case, however, war probably had an independent effect on prices: clove prices were twice as high in the 1820s as they had been in the first two decades of the century. This suggests that wartime disruption prevented clove prices from rising even faster in the wake of VOC abolition than they actually did. ${ }^{13}$

Table 3 summarises the discussion thus far, providing relative price information that is as far as possible comparable across countries. In particular, it shows the percentage by which war and blockades raised the price of importables, relative either to exportables, or to grain prices. This percentage impact was once again calculated by regressing the log of the relevant relative price on time, time squared, and dummy variables representing wartime (1798-1815, the start date being determined by the availability of French data) and the blockade period (taken to be 1807-14, so as to capture the effects of the Anglo-American war). ${ }^{14}$

Panel A looks at the relative price of wheat and textiles in Britain and France, and confirms that agricultural goods became relatively more expensive in Britain during the conflict, and that textiles became relatively more expensive in France. Figure 10 gives the two relative prices on one graph, and shows that they moved in a broadly similar fashion during the conflict, with British import price spikes in 1800-01 and 1814, and French import price spikes in 1804-5 and 1808-9. According to the regression estimates in Panel A, the

\footnotetext{
${ }^{13}$ Pepper was an exception during the 1820 s, however, with its price slipping slightly rather than rising.

14 The results in the column headed 'blockade' reflect the combined effects of both wars and blockades, and are calculated by adding together the coefficients on both dummy variables.
} 
average war-time impact in the two countries was very similar, while the blockade had roughly twice as big an impact in Britain as in France, raising relative import prices by approximately 40 percent and 20 percent in the two countries respectively. The results suggest that war-time attempts to disrupt trade in Europe worked, and if anything had a bigger impact on land-scarce and populous Britain than on the European continent, which had a comparative advantage in agricultural commodities, but was also a producer of textiles.

However, once the focus is switched to imports of non-European commodities, the picture is dramatically altered. Panel B looks at the relative price of a key European import from Asia, that is to say pepper, relative to both wheat and textiles, in Britain, France and the Netherlands. As can be seen, the price of pepper rose far more in France and the Netherlands than in Britain, no matter which numéraire is used. Its relative price more than doubled on the Continent during the blockade period, while rising by less than a third relative to textile prices in Britain. (Indeed, since wheat prices in Britain also rose, the price of pepper relative to wheat actually fell in Britain, a finding mirrored for sugar and cotton below.)

Panel $\mathrm{C}$ looks at the relative prices of European imports from the Americas (sugar and raw cotton, relative to both wheat and textiles), as well as American imports from Europe (textiles, wine and paper, relative to cotton and silver). Once again, relative import prices rose very substantially in France, Holland and Germany during the blockade period, and by a lot more than in Britain, even when textiles are used as the numéraire rather than wheat. It is noticeable that while relative sugar prices in France and the Netherlands were higher throughout the war, reflecting the collapse of Saint Domingue and British efforts to disrupt trade between the enemy and enemy colonies, relative cotton prices there only rose during the blockade period, when the neutral American trade with the Continent was also prohibited as a result of the British Orders in Council. Similarly, it was only during the blockade period, 
when Napoleon's policies were extended eastward, that the relative prices of cotton and sugar rose in Germany. Meanwhile, on the other side of the Atlantic the relative prices of textiles, wine and paper rose sharply. Comparing Britain and the US, it seems that the cotton/textiles relative price moved far more against the US than against the UK: Anglo-American economic and military warfare more than doubled the relative price of textiles in the US, but had only a small impact on British prices. ${ }^{15}$

The final two panels are calculated by comparing wartime prices with post-war prices, there being not enough data to carry out regression analysis. Panel D gives the relative price of imported goods relative to slaves in Africa; the goods imported into Africa consisted both of European manufactures, and re-exports of New World goods. In this case, it seems as though imports were relatively cheaper during the war than afterwards; this is due to the choice of 1816-20 as the peace-time benchmark (since real slave prices in West Africa fell after 1808, but continued falling right through the 1810s). Panel E gives the South East Asian price of silver, relative to cloves, pepper and coffee: the fact that these prices are only available decadally means that I cannot separate out the blockade years from the rest of the war, but with the exception of pepper mentioned earlier, the table shows large increases in the price of silver relative to local export goods when the first two decades of the $19^{\text {th }}$ century are compared with the 1820 s.

There are thus three main conclusions from the table. First, the war raised the relative price of importables nearly everywhere, often by significant amounts. Second, the increase in the relative price of importables was particularly pronounced during the blockade years, with

${ }^{15}$ The contrast between these results and those of Frankel (1982) are most likely explained by the different periods studied by the two papers; Frankel concentrates on the Embargo of 1807-9, while this study encompasses the more important British naval blockade of the United States in 1814. 
increases of more than $100 \%$, or even $200 \%$, being common. Third, a comparison of Britain with France, Holland and Germany suggests that the former's access to non-European goods was far less severely restricted during the conflict than that of its rivals. This can presumably be put down to British domination of the seas, which can also explain the greater impact of the conflict on import prices in the United States than in Britain, particularly during 1813-4.

It is clearly implausible to claim that the blockades and embargos of the French Revolutionary and Napoleonic Wars were so undermined by smuggling and corruption that they had no economic impact. Relative prices of importables rose substantially, relative prices of exportables fell, and by implication countries' terms of trade deteriorated, implying a decline in economic welfare. The next section estimates this welfare loss in four countries, Britain, France, the United States and Sweden.

\section{Section 5. Welfare losses: some simple estimates}

For a few countries, there are estimates of average export and import prices during this period, and hence of their aggregate terms of trade. Figure 11 graphs the price of imports, relative to the price of exports, for four such countries: the two main belligerents, Britain and France, as well as the United States and Sweden. The shaded area in the figures refers to the high-water mark of war-time trade restrictions, 1807-14. The figure indicates substantial increases in relative import prices during the conflict, consistent with the diplomatic and naval histories of the period. Sweden's terms of trade suffered a sharp deterioration in 1810 , when she was forced to join the Continental Blockade; while in France the terms of trade improved during the Peace of Amiens, before deteriorating dramatically during the period of the Blockade. The figure also bears out the impression given by the data on individual commodity prices, namely that Britain was less severely affected by these trade disputes than 
France, presumably as a result of the Royal Navy's supremacy at sea: intra-European trade disruption might have affected both of the main belligerents in a similar manner, and even raised import prices to a greater extent in Britain than in France (as Panel A of Table 3 suggested); but the impact of the wars on the price of non-European imports was so much greater on the Continent than in the British Isles that this swamped any other effects. Indeed, the effect of war on aggregate British relative import prices seems to be smaller than that in America as well: there were spikes in the relative price of imports in Britain in 1809 and 1814, but these were dwarfed by the enormous increase in the United States in 1814, when the Royal Navy successfully blockaded much of the US coastline. It looks therefore, as if Britain was the economic 'victor' in these trade disputes, emerging relatively unscathed while her rivals did not.

In order to take account of the fact that there were long run trends in these series (for example, rapid technological progress in key export industries such as textiles in Britain implied a long run tendency during this period for Britain's terms of trade to deteriorate: see Imlah 1958, Cuenca Esteban 1997), I once again regressed the log of each country's terms of trade on time and time-squared, plus a dummy variable representing the blockade period; and used the regression coefficients to infer how much lower relative import prices would have been in the absence of the blockade. According to this procedure, Britain suffered a terms of trade loss (i.e. higher relative import prices) of $11.9 \%$ during 1807-14, as compared with terms of trade losses of $8.6 \%$ in Sweden, $49.4 \%$ in the United States, and an impressive $61.2 \%$ in France. In the Swedish case, it makes sense to also look at the impact of the blockade from 1810 onwards, since it was only then that Sweden was forced to become a part of it: relative Swedish import prices were $21.0 \%$ higher during 1810-14 than during a noblockade counterfactual. 
In turn, these terms of trade effects reduced the economic welfare of the countries concerned. Estimates of the welfare loss depend on the economic model used to calculate them; I use the simplest possible computable general equilibrium (CGE) model that can generate such estimates. This is a simplification of the CGE model suggested by Anderson and Neary (1996) to estimate their trade restrictiveness index; and its appeal lies in the fact that the only information needed to calibrate the model is the trade share.

All production takes place in one sector, which uses a single factor of production (call it 'value added' or VA) to produce two composite outputs, a non-traded good (NT) which is entirely consumed, and an exportable good (X) which is entirely exported (see Figure 12). Production takes place according to a constant elasticity of transformation production function, with elasticity of transformation $\tau$. The exportable good is exchanged on international markets for a composite imported good, M, which is entirely consumed. The exportable is taken to be the numéraire good, and trade is assumed to be balanced. The key relative price in the model is then the (exogenous) relative price of the import good, which is set equal to one in the benchmark equilibrium, but can be changed in order to simulate the effects of terms of trade shocks. In order to calibrate the model, let the export share (equal to the import share by assumption) equal $t$, and assume that the country's endowment of value added equals 100 (the number chosen here is of course irrelevant to the results). Then the production of the non-traded good will equal $(1-t) * 100$; the production of the exportable will equal $t * 100$; and imports will equal $t * 100$. Consumption of the non-traded and imported goods will take place in the proportion (1-t) to $t$ respectively.

There are two key elasticities in the model: the elasticity of transformation $\tau$ between the non-traded good and the exportable in production, and the elasticity of substitution $\sigma$ in consumption between the non-traded good and the importable. The results depend in 
particular on the latter elasticity: the higher is the elasticity of substitution in consumption, the easier it is for consumers to switch away from imports when wartime blockades raise their price, and the lower the resultant welfare loss. Welfare losses should also depend on the value of $\tau$, with higher values leading to lower welfare losses; but in practice the results seem remarkably insensitive to the value of this parameter. I therefore follow Anderson and Neary in assuming a value of 5 for $\tau$ throughout.

Table 4 presents a range of welfare estimates for each country, for values of $\sigma$ ranging from 0.25 to 2 (the latter being an absolute upper bound, since typically CGE models assume elasticity values less than unity: see Irwin 2001). ${ }^{16}$ The results suggest that French welfare losses were roughly twice as high as British losses, lying in the $3-4 \%$ range, as opposed to British losses of 1.7-1.8\% per annum. Per annum losses were even lower in Sweden if the period $1807-14$ as a whole is considered, but were closer to $3 \%$ during $1810-1814$. The table thus confirms the earlier impression that the blockades hit Britain much less severely than they did her main Continental rival.

The most striking result of Table 4, however, concerns a country which had initially been neutral, namely the United States. The results suggests that per annum American welfare losses were much higher than those incurred in either France of Britain, lying in the $5-6 \%$ range. These estimates are remarkably close to Irwin's estimate of a 5\% welfare loss for the United States during the period of Jefferson's embargo; the difference is that these are average estimates calculated for the period $1807-14$ as a whole, since, as the terms of trade figures suggest, wartime curtailment of trade continued to impose a cost on the American economy well after the repeal of the Embargo Act. Indeed, the terms of trade data suggest that

${ }^{16}$ Anderson and Neary's baseline assumption is that $\sigma=0.7$. 
the American welfare losses actually reached a peak in 1814.

Welfare losses of 5 to $6 \%$ per annum over an eight year period were a substantial burden: the final two rows of Table 4 show that the cumulative welfare loss amounted to $36 \%$ in the United States, equivalent to a permanent flow loss of $1.8 \% .{ }^{17}$ To put these losses in perspective, as already mentioned Glick and Taylor estimate that the permanent flow losses associated with the trade disruption of World War I amounted to $2.74 \%$ for belligerents, and $2.09 \%$ for neutrals. Strikingly, American losses associated with the trade disruption of the Napoleonic Wars were almost as big as the latter figure; and my estimates do not even take into account any losses incurred between 1793 and 1806 inclusive. Permanent flow losses were lower for the other countries considered here, a notable fact given that France and Britain were the two main belligerents during the conflict (they amounted to $1.12 \%$ p.a. in France, $0.6 \%$ in Britain and $0.42-0.65 \%$ p.a. in Sweden), but they were still very substantial. Furthermore, Table 3 suggests that welfare losses are also likely to have been high in the Netherlands and Latin America. ${ }^{18}$

Clearly, it is not the case that wartime trade disruption imposes equal penalties on all belligerents, or indeed on all neutrals; nor would one expect this to be the case. The average correlations that would have been revealed in a cross-sectional regression, had I had the data with which to perform it, would have masked important variations across countries. First,

${ }^{17}$ The estimates let $\sigma$ equal 0.7 , and assume a discount rate of $5 \%$, to make them comparable with the Glick and Taylor results. The cumulative loss is simply the discounted value, in 1807, of the annual welfare losses (given in the row headed ' $\mathrm{s}=0.7$ ') for each of the years 1807-14; while the permanent flow loss is the per annum permanent loss which would produce the same discounted cumulative loss.

${ }^{18}$ Indeed, it could be argued that this model will understate the welfare effects of war and blockades, at least in a country like Britain where unemployment became a problem during 1808 and 1811-12 (as emphasised by Crouzet 1987). 
countries suffered different terms of trade shocks; and second, some were more open to trade, and thus more exposed to trade shocks, than others. The terms of trade shocks were larger in France than in any other country, but France was also much less open, implying that French welfare losses, while very considerable, were lower than in the United States. Crucially, terms of trade shocks were substantially lower in Britain (and Sweden), implying smaller welfare losses there, in spite of the relatively open nature of both economies. Having control of the seas, as was the case for Britain in the early $19^{\text {th }}$ century, proved far more useful in terms of waging economic warfare than did the land-based power of Napoleon (O'Brien 2003).

\section{Section 5. Conclusion}

Clearly, the wars of 1793-1815 had important, world-wide, effects on trade and economic welfare, which were particularly burdensome during the years of the Continental Blockade and the disputes between Britain and the United States, culminating in the British blockade of the US in 1814. The very large welfare costs imposed on the young United States, which had started out as a neutral party to the conflict, are especially noteworthy. Moreover, the wars' effects continued to be felt in the trade policies of the main belligerents long after the conflict had ended. For example, in Britain rents rose substantially towards the end of the war: not surprisingly, landowners were reluctant to give up these gains. The result was political lobbying that gave rise to the Corn Law of 1815 , which meant in practice that domestic markets were closed to foreign grain for most of the seven years following 1816 . While this law was gradually relaxed in the succeeding decades, it was only finally repealed in 1846 .

When Europe eventually moved towards freer trade in the late $19^{\text {th }}$ century, this was largely as a result of Britain's example; might Britain have liberalized earlier had the 
Napoleonic Wars not intervened? Such an argument assumes that industrialization (which would have proceeded more rapidly in the absence of the war) ${ }^{19}$ would have led to the emergence of powerful export interests, which would have eventually triumphed as their political power grew. Would the extension of the franchise favouring urban interests, and thus the free trade cause, have predated the 1832 Reform Act, had war not occurred? (Surely the Revolution and succeeding wars did nothing to hasten liberal reforms in Britain.) Alternatively, might landlords have diversified into non-agricultural interests earlier, and been coopted by the free trade side as eventually happened (Schonhardt-Bailey 1991)? Did the Napoleonic Wars delay the advent of free trade in Britain and Europe, by as much as several decades?

While it is near impossible to provide definitive answers to such questions, a hint that the Napoleonic Wars did significantly delay the advent of free trade in Britain can be found with the passage of the Eden Treaty between Britain and France in 1786. This treaty "put an end to the hundred years' commercial war" between the two countries, abolishing prohibitions on imports, and reducing tariffs generally, "usually down to 10 or 15 per cent" (Heckscher 1922, p. 20). It is true that, even in the absence of war between the two countries, this treaty might eventually have lapsed; Heckscher (1922, pp. 20-23) reports that the treaty led to widespread complaints from a variety of French industries, notably the French textile industry, and one can certainly speculate that this pressure would eventually have born fruit. On the other hand, the new post-revolutionary French tariff of 1791 contained only moderate additional protection, despite widespread protectionist pressure. It was only in early 1793 , when tensions between the two countries were mounting, and shortly before war broke out

\footnotetext{
${ }^{19}$ Williamson (1984).
} 
between them, that the French denounced the Eden Treaty. And it was the French who denounced the Treaty, not the British, whose leaders had at this stage already been influenced by the ideas of Adam Smith and other economic liberals. There is thus a prima facie case that the French and Napoleonic Wars delayed the adoption of free trade policies in Britain, maybe even by several decades. ${ }^{20}$

Meanwhile, on the French side of the English Channel war also had predictable political economy effects, although here the sectoral patterns of winners and losers were somewhat more complicated. In particular, whereas in Britain it was the case that agriculture, broadly speaking, gained from warfare, and that industry lost, in France there were winners and losers within industry itself (Crouzet 1964). Industries which were linked with the Atlantic trade, such as sugar-refining, the linen industry, ship building, rope-making, and sailmaking were seriously affected by the Royal Navy's sea blockade, as well as the slave revolt on Saint Domingue; on the other hand, those industries which had complained about the Eden Treaty, and the consequent increase in British competition, presumably benefited. As noted in Table 3, the blockade raised the price of textiles by some $20 \%$ during $1807-12$, relative to the price of wheat, and so one would expect that it was the import-competing cotton textiles industry that was the most important winner in France. This is the position taken by Crouzet (1964), according to whom machine spinning was boosted enormously by the restrictions on cotton yarn imports imposed from 1806. Thus, the output of machine-spun yarn quadrupled between 1806 to 1810 , with a spectacular growth in the number of spindles in northern and eastern French cities such as Lille and Mulhouse, as well as in regions such as Belgium and

${ }^{20}$ A counter-argument might be that British hegemony, and thus war ending with British victory over the French, might have been required for the widespread trade liberalisation of the long $19^{\text {th }}$ century: see below. 
Saxony (where the number of mule spindles rose from 13,000 in 1806 to 256,000 in 1813) (Crouzet 1964, p. 576). On the other hand, both Heckscher (1922) and Chabert (1949) stress another effect of the blockades, which was also seen earlier: namely, the dramatic increase in the price of raw cotton, which rose by more in France (relative to the price of textiles) than in Britain during the period. Thus, according to Chabert (p. 130) the scarcity of raw materials made it more and more difficult for the French cotton industry to remain competitive. The difference in emphasis of these authors is perhaps not so fundamental, however: on the one hand, Heckscher (pp. 269-282) implicitly accepts that the blockade stimulated the growth of the industry (and provides as evidence the industry's collapse in 1814, when the country's frontiers were opened after Napoleon's fall); on the other hand, Crouzet accepts that high raw cotton prices (especially after 1808) hampered the growth of the French industry, which may have grown during the blockade years, but less rapidly than its British counterpart. The question is whether it would have grown at all if the Eden Treaty provisions had continued to apply; the answer of both authors seems, on balance, to be negative.

More to the point, perhaps, Chabert (1949, pp. 347-9) reports that profits rose more rapidly during the war in France than any other category of income, and that this was true of the textile industry despite its high raw materials costs: he reports several cases of cotton spinners and other industrialists who made large fortunes during the wars. Naturally, Continental industries which had managed to prosper under these wartime circumstances, but were uncompetitive internationally, were unlikely to favour peacetime moves towards free trade; after the war they clamoured for protection, and, as Crouzet points out, they generally obtained it. In this way, the consequences for post-1815 French trade policy were to prove quite persistent.

Something very similar happened in the United States, which represents the polar 
opposite of the British case, since wartime unambiguously favoured American manufacturers. In 1790 , there were just 2,000 cotton spindles in the United States, as opposed to over 2 million in Britain, and by 1809 this number had only grown to 8,000. However, the number of American spindles then began to soar, reaching 93,000 in 1812 and 333,000 in 1817 (Rosenbloom 2002, Table 1). Thus, the take-off of the American cotton textiles industry coincided exactly with the virtual elimination of imports from Britain. This makes sense: Table 3 shows that the price of textiles in the United States, relative to raw cotton, was twice as high during 1807-12 as it was during 1816-20; this should have boosted the industry's profits, in contrast to the situation in Britain and France. Furthermore, the industry went into decline in 1815 and 1816, once the war had ended. Rosenbloom (2002) recounts how New England textile manufacturers such as Francis Lowell set out to protect the new industry; their efforts were soon rewarded, since the 1816 tariff bill established a minimum valuation for cotton cloth imports, which effectively excluded low-cost Indian fabrics from the American market. The fact that Indian manufacturers did not use American cotton made it easier for the bill to pass in the face of the objections of southern Congressmen, representing US export interests; however, in the years to come northern manufacturers would continue to press for protection, resulting both in tension between North and South, and in high levels of manufacturing protection during most of the $19^{\text {th }}$ century. Thus, once again the disintegrating effects of war were propagated through domestic political processes.

Thus far, this paper has stressed the negative effects of the Twenty-Three Years War on trade and welfare; and these were indeed considerable. But the conflict had other, longerrun and more systemic effects which ran in the other direction, and it would be wrong to conclude the paper without mentioning these.

First, one of the most striking long run impacts of the conflict of these years was the 
virtual collapse of Europe's New World empires, and the transformation of the Americas into a land mass divided into independent states. To be sure, these states were now able to pursue their own commercial policies, and on the whole chose to impose high tariffs on imports (Coatsworth and Williamson 2004). On the other hand, however, mercantilist efforts to privilege bilateral trade between New World colonies and their mother countries, at the expense of multilateral trade, now lapsed. This had an immediate effect, as can be seen, for example, by the increase in British exports to Latin America during and after the Napoleonic Wars. In the mid-1780s, Latin America had accounted for just $0.06 \%$ of British manufactured exports; the proportion was $3.3 \%$ in $1804-6,6.3 \%$ during $1814-6$, and $15 \%$ in the mid- $1820 \mathrm{~s}$ (Davis 1979, p. 88).

Second, traditional mercantilist restrictions on trade between Europe and Asia were also disintegrating during the period, and again war was at least a proximate cause. In Holland, the VOC was severely weakened by the Fourth Anglo-Dutch War of 1780-84, losing half its ships; while it had not been profitable for some time, it now became "a ward of the state" (de Vries and van der Woude 1997, p. 455). When the French revolutionaries invaded the Netherlands in 1795, and the Batavian Republic was declared, the VOC's activities were taken over by the government, who found, however, that war made trade with Asia next to impossible. In 1806, the Dutch government permitted free trade with Asia (ibid., p. 456). Meanwhile, the English East India Company lost its monopoly on the trade with India in 1813 , following a very partial relaxation of this monopoly in 1793. According to Webster (1990), this decision was also a by-product of wartime conditions: in an inflationary environment in which many imports were in scarce supply, and with consequent fears of social unrest, it became more difficult to justify trade monopolies caused by British legislation and which further restricted supplies. 
The English East India Company would to hang on to its monopoly of the AngloChinese trade until 1833; however, the Napoleonic wars brought to an end the era of great European trading monopolies. While this did not imply the dawn of a free-trading Golden Age, the typical trade restriction of the long $19^{\text {th }}$ century would be a tariff, rather than the nontariff barriers which had distinguished the $18^{\text {th }}$ century, and which would distinguish the $20^{\text {th }}$ century. International trade between 1815 and 1914 would thus be conducted on a more multilateral basis than had been true before, a tendency that was further strengthened in 1860 when the Cobden-Chevalier Treaty placed the MFN principle at the heart of European commercial policy.

Third, by the war's end Britain was firmly established as the world's dominant power, and especially as its dominant naval power. The French had lost Haiti, their major Caribbean possession and source of colonial imports, while by 1830 the Spanish presence in the New World had been reduced to Cuba and Puerto Rico. The Dutch had lost the South African Cape Colony and Ceylon to Britain, as well as territories in the West Indies; more importantly, Amsterdam's once central role in international trade had been destroyed, as a result of the combined effects of the British blockade, the French Continental System, and French Imperial protectionism (de Vries and van der Woude 1997, p. 687). One measure of British immediate post-war dominance is her share of world shipping, which had been just $17.9 \%$ in 1670 ; it jumped from $25.3 \%$ in 1780 to an impressive $42 \%$ in 1820 (Maddison 2001, p. 95). And as Patrick O'Brien (1989, p. 383) points out, British military hegemony at sea was an important precondition for the broadly liberal international economy of the long $19^{\text {th }}$ century.

Finally, the wars of 1793-1815 were such a traumatic event that they produced a surprisingly durable peace settlement. In Paul Schroeder's view, the political equilibrium 
which emerged from the Congress of Vienna rested on "a mutual consensus on norms and rules, respect for law, and an overall balance among the various actors in terms of rights, security, status, claims, duties and satisfactions rather than power" (Schroeder 1992, p. 694). Rather than relying on an unattainable balance of power, the Congress implicitly recognized British and Russian hegemony in their respective spheres of influence (the wider globe, and Eastern Europe and much of Asia respectively); but the hegemony was relatively benign, and the entire system relied on "the restoration of the rule of law, beginning with its foundation, the security and legitimacy of all thrones" (Schroeder 1992, p. 696). While the Vienna system ultimately failed, the fact remains that battlefield deaths as a proportion of Europe's population were seven times more numerous in the $18^{\text {th }}$ century than they were in the $19^{\text {th }}$ (Schroeder 1994, p. vii), and the $19^{\text {th }}$ century stands out as an unusually peaceful one in the context of Europe's bloody history. Thus European wars were less important during this canonical globalization period than they have been before or since; and this is surely no coincidence.

In conclusion, therefore, while the Revolutionary and Napoleonic Wars seriously disrupted trade for three decades, and led to huge economic losses and human casualties, they ultimately played a crucial role in modernising the international economy, and thus helped pave the way for the astonishing international economic integration which was to follow. 


\section{References}

Anderson, J.E. and J.P. Neary (1996), “A New Approach to Evaluating Trade Policy,” Review of Economic Studies 63: 107-125.

Bayly, C.A. (2003), The Birth of the Modern World, 1780-1914: Global Connections and Comparisons (Blackwell).

Beveridge, W.H. (1939), Prices and Wages in England from the Twelfth to the Nineteenth Century, Vol. I: Price Tables: Mercantile Era (London: Longmans, Green and Co.).

Brown, K.W. (1990), "Price Movements in Eighteenth-Century Peru: Arequipa," in L.L. Johnson and E. Tandeter (eds.), Essays on the Price History of Eighteenth-Century Latin America (Albuquerque: University of New Mexico Press), 173-200.

Bulbeck, D., A. Reid, L.C. Tan and Y. Wu (1998), Southeast Asian Exports Since the $14^{\text {th }}$ Century: Cloves, Pepper, Coffee, and Sugar (Leiden, The Netherlands: KITLV Press).

Bulmer-Thomas, V. (2003), The Economic History of Latin America Since Independence, $2^{\text {nd }}$ edition (Cambridge: Cambridge University Press).

Chabert, A. (1945), Essai sur les Mouvements des Prix en France de 1798 à 1820 (Paris: Librairie des Médicis).

Chabert, A. (1949), Essai sur les Mouvements des Revenus et de l'Activité Economique en France de 1798 à 1820 (Paris: Librairie des Médicis).

Coatsworth, J.H. and J.G. Williamson (2004), "Always Protectionist? Latin American Tariffs from Independence to Great Depression," Journal of Latin American Studies 36: 205-232.

Cole, A.H. (1938), Wholesale Commodity Prices in the United States 1700-1861

(Cambridge, Massachusetts: Harvard University Press).

Cole, A.H. and R. Crandall (1964), "The International Scientific Committee on Price History," Journal of Economic History 24: 381-388.

Crouzet, F. (1964), “Wars, Blockade, and Economic Change in Europe, 1792-1815," Journal of Economic History 24: 567-588.

Crouzet, F. (1987), L'Economie Brittanique et Le Blocus Continental, $2^{\text {nd }}$ edition (Paris: Economica).

Crouzet, F. (2003), "The Continental System After Eighty Years," paper presented at the Eli Heckscher Celebratory Symposium, Stockholm School of Economics, May 22-24.

Cuenca Esteban, J. (1997), "The Rising Share of British Industrial Exports in Industrial Output, 1700-1851," Journal of Economic History 57: 879-906. 
Cuenca Esteban, J. (2004), "Comparative Patterns of Colonial Trade: Britain and its Rivals," in L. Prados de la Escosura (ed.), Exceptionalism and Industrialisation: Britain and its European Rivals, 1688-1815 (Cambridge: Cambridge University Press), 35-66.

Davis, L.E. and S.L. Engerman (forthcoming), Blockades in Peace and War: An Economic History of Naval Blockades Since the Middle of the Eighteenth Century.

Davis, R. (1962), “English Foreign Trade, 1700-1774,” Economic History Review New Series, 15: 285-303.

Davis, R. (1979), The Industrial Revolution and British Overseas Trade (Leicester University Press).

Dermigny, L. (1964), La Chine et l'Occident: Le Commerce à Canton au XVIII Siècle 17191833, Tome III (Paris: S.E.V.P.E.N.).

Eaton, J. and M. Engers (1999), "Sanctions: Some Simple Analytics," American Economic Review, Papers and Proceedings 89: 409-414.

Ellis, G. (1981), Napoleon's Continental Blockade: The Case of Alsace (Oxford: Clarendon Press).

Engerman, S.L. (1981), "Some Implications of the Abolition of the Slave Trade," in D. Eltis and J. Walvin (eds.), The Abolition of the Atlantic Slave Trade: Origins and Effects in Europe, Africa, and the Americas (Madison, Wisconsin: University of Wisconsin Press).

Findlay, R. and K.H. O'Rourke (2003), “Commodity market integration, 1500-2000," in M.D. Bordo, A.M. Taylor and J.G. Williamson (eds.), Globalization in Historical Perspective (University of Chicago Press/NBER 2003), 13-62.

Frankel, J.A. (1982), “The 1808-1809 Embargo against Great Britain,” Journal of Economic History 42: 291-307.

Frankel, J.A. and D. Romer (1999), "Does Trade Cause Growth?” American Economic Review 89: 379-399.

Gayer, A.D., W.W. Rostow and A.J. Schwartz (1953), The Growth and Fluctuation of the British Economy 1790-1850 (Oxford: Clarendon Press).

Glick, R. and A.M. Taylor (2005), "Collateral Damage: The Economic Impact of War, 18701997," mimeo.

Hauser, H. (1936), Recherches et Documents sur l'Histoire des Prix en France de 1500 à 1800 (Paris: Les Presses Modernes).

Heckscher, E.F. (1964), The Continental System: An Economic Interpretation (Gloucester, MA: Peter Smith). Reprint of 1922 edition. 
Hueckel, G. (1973), "War and the British Economy, 1793-1815: A General Equilibrium Analysis," Explorations in Economic History 10: 365-396.

Hufbauer, G.C., J.J. Schott and K.A. Elliott (1990), Economic Sanctions Reconsidered: History and Current Policy, $2^{\text {nd }}$ edition (Washington D.C.: Institute for International Economics).

Imlah, A.H. (1958), Economic Elements in the Pax Britannica (Cambridge, Massachusetts: Harvard University Press).

Irwin, D.A. (2001), "The Welfare Effects of Autarky: Evidence from the Jeffersonian Embargo,” NBER Working Paper No. 8692 (December). Revised, November 2002.

Jacobs, A. and H. Richter (1935), Die Großhandelspreise in Deutschland von 1792 bis 1934 (Berlin: Hanseatische Verlaganstalt Hamburg).

Jörberg, L. (1972), A History of Prices in Sweden 1732-1914, Volume 1 (Lund: CWK Gleerup).

Lévy-Leboyer, M. (1970), “L'héritage de Simiand: Prix, Profit et termes d'échange au XIX Siècle," Revue Historique 493: 77-120.

Lévy-Leboyer, M. and F. Bourguignon (1990), The French Economy in the Nineteenth Century: An Essay in Econometric Analysis (Cambridge: Cambridge University Press).

Lovejoy, P.E. and D. Richardson (1995), "British Abolition and its Impact on Slave Prices Along the Atlantic Coast of Africa, 1783-1850," Journal of Economic History 55: 98-119.

Maddison, A. (2001), The World Economy: A Millennial Perspective (Paris: OECD).

McCusker, J.J. (1996), "British Mercantilist Policies and the American Colonies," in S.L. Engerman and R.E. Gallman (eds.), The Cambridge Economic History of the United States, Volume I: The Colonial Era (Cambridge: Cambridge University Press), 337-362.

Mitchell, B.R. (1988), British Historical Statistics (Cambridge: Cambridge University Press).

Neal, L. (1991), “A Tale of Two Revolutions: International Capital Flows 1789-1819," Bulletin of Economic Research 43: 57-92.

Newland, C. (1998), "Exports and Terms of Trade in Argentina, 1811-1870," Bulletin of Latin American Research 17: 409-416.

North, D.C. (1966), The Economic Growth of the United States 1790-1860 (New York: Norton).

O'Brien, P.K. (1989), “The Impact of the Revolutionary and Napoleonic Wars, 1793-1815, on the Long-Run Growth of the British Economy," Review XII: 335-395. 
O'Brien, P.K. (2003), "The Hanoverian State and the Defeat of the Continental System," paper presented at the Eli Heckscher Celebratory Symposium, Stockholm School of Economics, May 22-24.

Olson, M. (1963), The Economics of the Wartime Shortage: A History of British Food Supplies in the Napoleonic War and in World Wars I and II (Durham, N.C.: Duke U.P.).

O'Rourke, K.H. and J. G. Williamson (2002a), “After Columbus: Explaining the Global Trade Boom 1500-1800," Journal of Economic History 62: 417-456.

O'Rourke, K.H. and J. G. Williamson (2002b), “When Did Globalization Begin?” European Review of Economic History 6: 23-50.

Posthumus, N.W. (1946), Inquiry Into the History of Prices in Holland, Vol. I (Leiden: Brill).

Rose, J.H. (1902), “Our Food Supply in the Napoleonic War,” Monthly Review 6: 63-76.

Rosenbloom, J.L. (2002), "Path Dependence and the Origins of Cotton Textile Manufacturing in New England," NBER Working Paper No. 9182 (September).

Salvatore, R.D. and C. Newland (2003), "Between Independence and the Golden Age: The Early Argentine Economy," in G. della Paolera and A.M. Taylor (eds.), A New Economic History of Argentina (Cambridge: Cambridge University Press), 19-45.

Schonhardt-Bailey, C. (1991), "Specific Factors, Capital Markets, Portfolio Diversification, and Free Trade: Domestic Determinants of the Repeal of the Corn Laws," World Politics 43: 545-69.

Schön, L. (1984), “Svensk Utrikeshandel 1800-1871,” mimeo, Lund.

Schroeder, P.W. (1992), "Did the Vienna Settlement Rest on a Balance of Power?" American Historical Review 97: 683-706.

Schroeder, P.W. (1994), The Transformation of European Politics 1763-1848 (Oxford: Clarendon Press).

Tandeter, E. and N. Wachtel (1990), "Prices and Agricultural Production: Potosí and Charcas in the Eighteenth Century," in L.L. Johnson and E. Tandeter (eds.), Essays on the Price History of Eighteenth-Century Latin America (Albuquerque: University of New Mexico Press), 201-276.

U.S. Department of Commerce (1975), Historical Statistics of the United States, Bicentennial Edition: Colonial Times to 1970, Part 1 (Washington, D.C.: Bureau of the Census).

Vamplew, W. (ed.) (1987). Australian Historical Statistics (Broadway, New South Wales: Fairfax, Syme and Weldon). 
Vilar, P. (1976), A History of Gold and Money 1450-1920 (London: NLB).

de Vries, J. and A. van der Woude (1997), The First Modern Economy: Success, Failure, and Perseverance of the Dutch Economy, 1500-1815 (Cambridge: Cambridge University Press).

Warren, G.F. and F.A. Pearson (1933), Prices (New York: Wiley).

Webster, A. (1990), “The Political Economy of Trade Liberalization: The East India Company Charter Act of 1813,” Economic History Review, New Series 43: 404-419.

Williamson, J.G. (1984), "Why was British Growth so Slow During the Industrial Revolution?," Journal of Economic History 44: 687-712. 
Table 1 Impact of blockades on trade volumes, 1807-14

(Percent change in trade relative to no-blockade counterfactual)

\begin{tabular}{lcc}
\hline & Exports & Imports \\
\hline Britain & -4.1 & 2.1 \\
France & 4.3 & $\mathbf{- 5 1 . 6}$ \\
Sweden & 7.1 & $\mathbf{2 2 . 4}$ \\
U.S. & $\mathbf{- 3 6 . 3}$ & $\mathbf{- 5 2 . 8}$ \\
\hline
\end{tabular}

Source: see Appendix 1 and text. 
Table 2. South East Asian silver prices, 1770s-1820s

\begin{tabular}{lccc}
\multicolumn{4}{c}{$(1770 \mathrm{~s}=100)$} \\
\hline & Cloves & Pepper & Coffee \\
\hline $1770 \mathrm{~s}$ & 100.0 & 100.0 & 100.0 \\
$1780 \mathrm{~s}$ & NA & 100.0 & 100.7 \\
$1790 \mathrm{~s}$ & NA & 82.2 & 100.0 \\
$1800 \mathrm{~s}$ & 131.6 & 153.4 & 33.8 \\
$1810 \mathrm{~s}$ & 131.6 & 134.4 & 87.8 \\
$1820 \mathrm{~s}$ & 266.5 & 118.8 & 143.2 \\
\hline
\end{tabular}

Source: Bulbeck et al. (1998), pp. 59, 84, 168. 
Table 3. Price impact of Napoleonic Wars

(percentage increase in relative price relative to peace-time counterfactual)

\begin{tabular}{|c|c|c|c|}
\hline Relative price & Country & War & Blockade \\
\hline \multicolumn{4}{|c|}{ Panel A. Intra-European } \\
\hline Wheat/textiles & Britain & 19.03 & 41.35 \\
\hline Textiles/wheat & France & 16.58 & 19.84 \\
\hline Textiles/wheat & Germany & 6.74 & 5.71 \\
\hline \multicolumn{4}{|c|}{ Panel B. Europe-Asia } \\
\hline \multirow[t]{3}{*}{ Pepper/wheat } & France & 66.53 & 216.36 \\
\hline & Britain & -27.22 & -8.21 \\
\hline & Holland & 1.41 & 119.46 \\
\hline \multirow{3}{*}{ Pepper/textiles } & France & 19.10 & 109.82 \\
\hline & Britain & -13.37 & 29.74 \\
\hline & Holland & 15.13 & 167.37 \\
\hline \multicolumn{4}{|c|}{ Panel C. Europe-Americas } \\
\hline \multirow[t]{4}{*}{ Sugar/wheat } & France & 63.31 & 195.03 \\
\hline & Britain & 16.31 & -2.90 \\
\hline & Holland & 17.87 & 165.10 \\
\hline & Germany & 2.43 & 143.09 \\
\hline \multirow[t]{4}{*}{ Raw cotton/wheat } & France & -6.46 & 114.28 \\
\hline & Britain & -10.96 & -26.17 \\
\hline & Holland & -9.47 & 11.45 \\
\hline & Germany & -28.70 & 67.89 \\
\hline \multirow[t]{4}{*}{ Sugar/textiles } & France & 26.70 & 125.59 \\
\hline & Britain & 38.44 & 37.25 \\
\hline & Holland & 25.27 & 214.64 \\
\hline & Germany & -4.04 & 129.95 \\
\hline \multirow[t]{4}{*}{ Raw cotton/textiles } & France & -19.76 & 78.81 \\
\hline & Britain & 6.43 & 4.93 \\
\hline & Holland & -2.31 & 31.23 \\
\hline & Germany & -33.20 & 58.82 \\
\hline Textiles/Raw cotton & USA & 106.01 & 182.51 \\
\hline Wine/raw cotton & USA & 28.59 & 137.05 \\
\hline Rouen cloth/silver & Peru (Arequipa) & 12.92 & 91.58 \\
\hline Paper/silver & Peru (Arequipa) & 53.19 & 120.79 \\
\hline Paper/silver & Peru (Lima) & 46.87 & 111.77 \\
\hline \multicolumn{4}{|c|}{ Panel D. Africa-Europe/Americas } \\
\hline Imports/slaves & Africa & $-48.49^{\mathrm{a}}$ & $-32.37^{b}$ \\
\hline \multicolumn{4}{|c|}{ Panel E. Asia-Europe/Americas } \\
\hline Silver/cloves & South East Asia & $102.51^{\mathrm{c}}$ & NA \\
\hline Silver/pepper & South East Asia & $-17.44^{\mathrm{c}}$ & NA \\
\hline$\underline{\text { Silver/coffee }}$ & South East Asia & $135.53^{\mathrm{c}}$ & NA \\
\hline
\end{tabular}

Source: see Appendix 1 and text. S.E. Asian prices are taken from Table 2; African prices are from Lovejoy and Richardson (1995, Table 2, column 6, p.108).

a $1798-1814 / 1815-20$

b $1808-14 / 1815-20$

${ }^{c} 1801-20 / 1821-30$. 
Table 4. Estimates of welfare loss (percent)

\begin{tabular}{|c|c|c|c|c|c|}
\hline $\begin{array}{l}\text { Country } \\
\text { Period }\end{array}$ & $\begin{array}{c}\text { Britain } \\
1807-14 \\
\end{array}$ & $\begin{array}{c}\text { France } \\
1807-14 \\
\end{array}$ & $\begin{array}{c}\text { USA } \\
1807-14 \\
\end{array}$ & $\begin{array}{l}\text { Sweden } \\
1807-14 \\
\end{array}$ & $\begin{array}{l}\text { Sweden } \\
1810-14 \\
\end{array}$ \\
\hline Terms of trade shock (percent increase in relative import price) & 11.9 & 61.2 & 49.4 & 8.6 & 21.0 \\
\hline Trade share (percent) & 15.7 & 6.6 & 13.0 & 15.0 & 15.0 \\
\hline \multicolumn{6}{|c|}{ Welfare Effects (percent decline) } \\
\hline $\mathrm{s}=0.25$ & 1.8 & 3.8 & 5.9 & 1.3 & 3.0 \\
\hline $\mathrm{s}=0.5$ & 1.8 & 3.5 & 5.6 & 1.3 & 2.9 \\
\hline $\mathrm{s}=0.7$ & 1.8 & 3.3 & 5.4 & 1.2 & 2.9 \\
\hline $\mathrm{s}=1.0$ & 1.7 & 3.1 & 5.1 & 1.2 & 2.8 \\
\hline $\mathrm{s}=2.0$ & 1.7 & 2.6 & 4.4 & 1.2 & 2.6 \\
\hline Cumulative loss ( $\mathrm{s}=0.7,5 \%$ discount rate) & 12.0 & 22.4 & 36.1 & 8.4 & 13.1 \\
\hline Permanent flow loss ( $\mathrm{s}=0.7,5 \%$ discount rate) & 0.60 & 1.12 & 1.81 & 0.42 & 0.65 \\
\hline
\end{tabular}

Source: see text. 

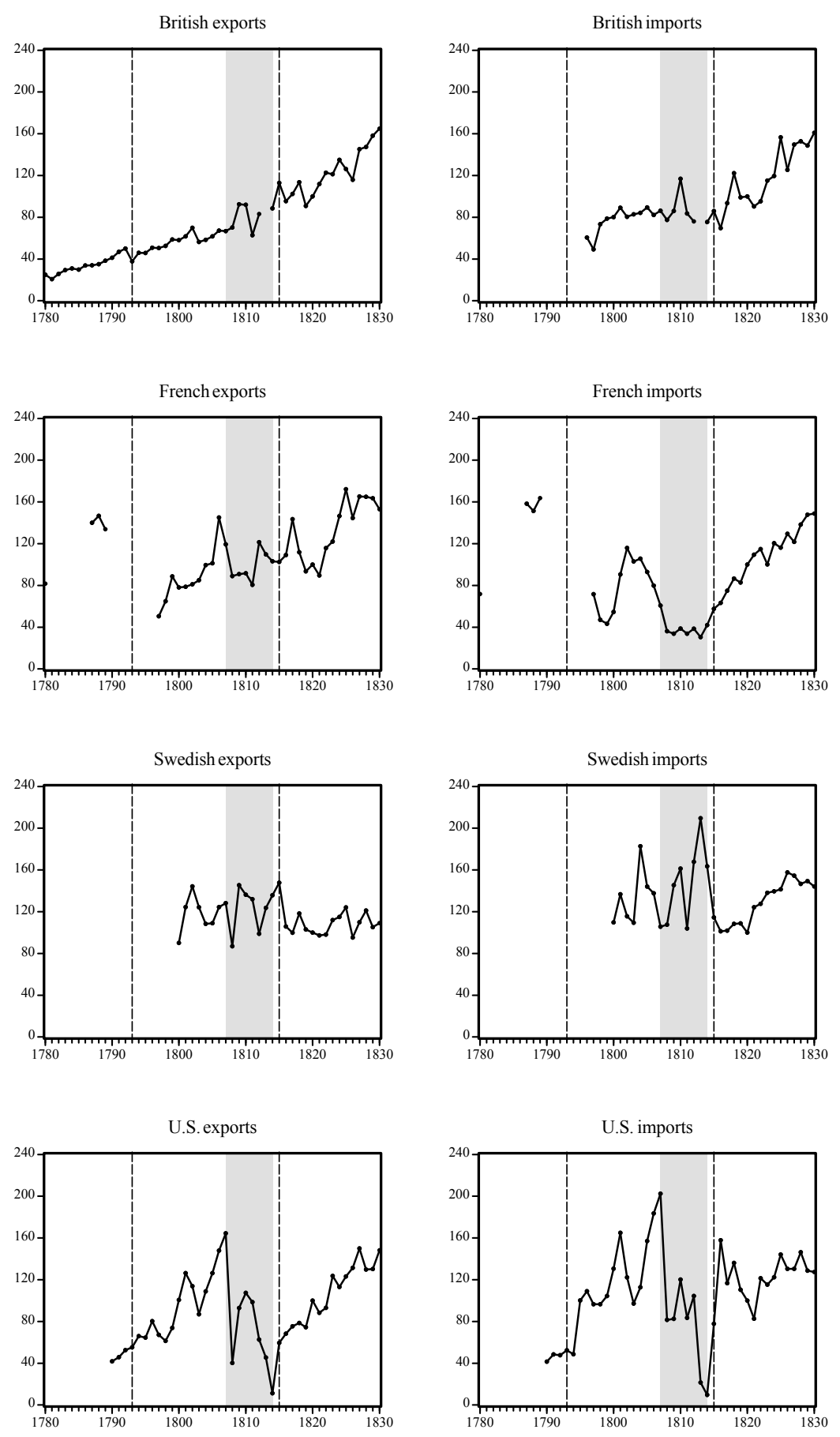

Figure 1. Volume of trade, 1780-1830 $(1820=100)$

Source: see Appendix 1. 


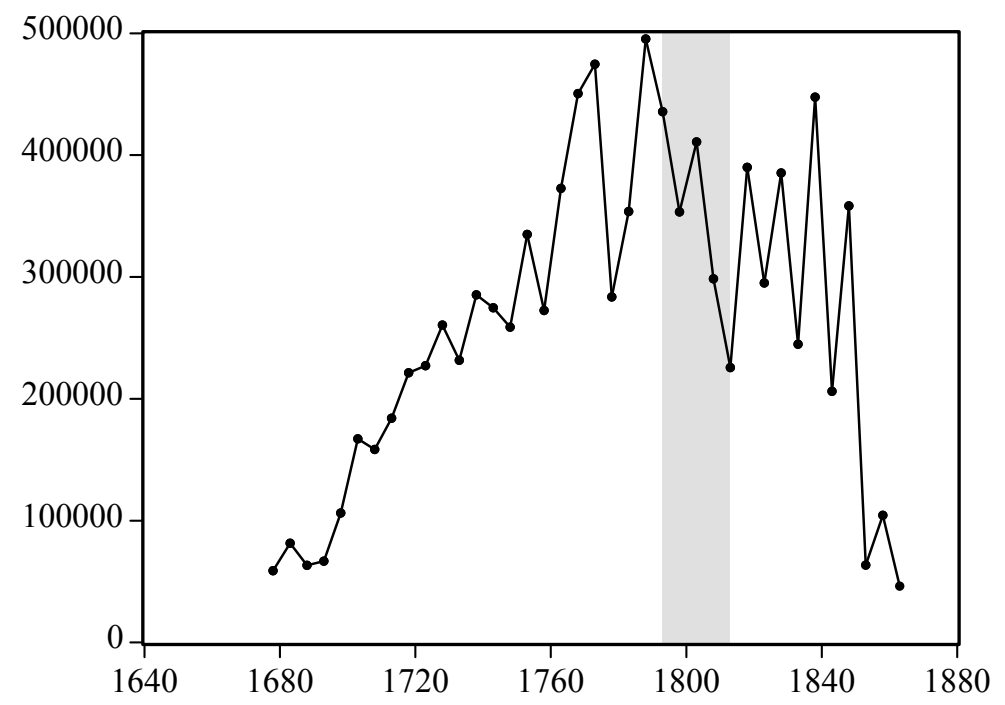

Figure 2. African slave exports, 1676-1865

Source: data underlying Eltis (2001), kindly provided by author. 

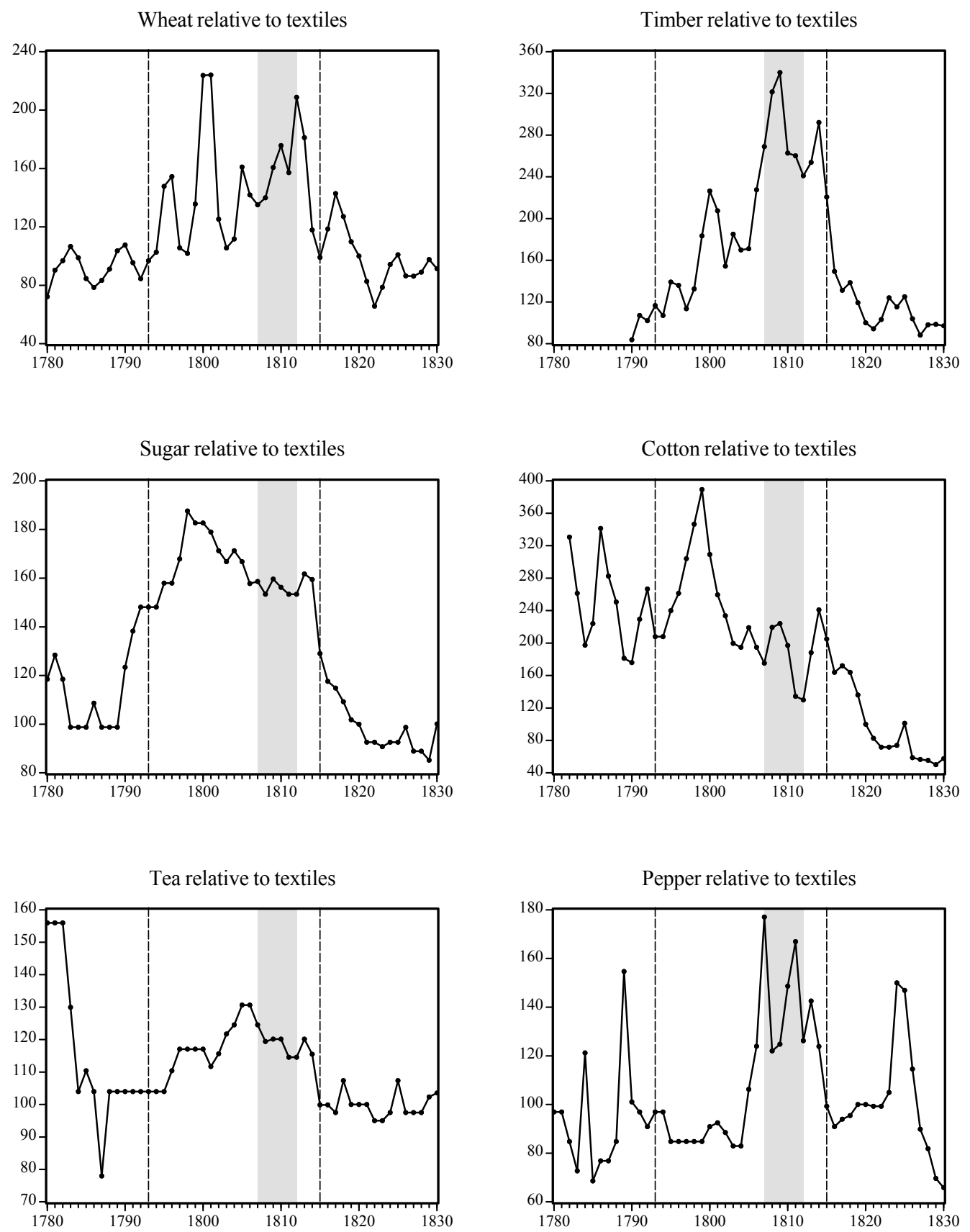

Source: see Appendix 1.

Figure 3. Relative prices in Britain, 1780-1830 (1820=100) 
Textiles relative to wheat

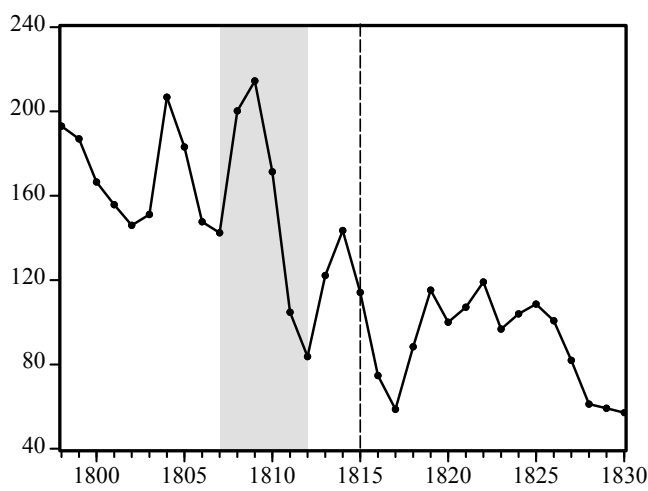

Sugar relative to textiles

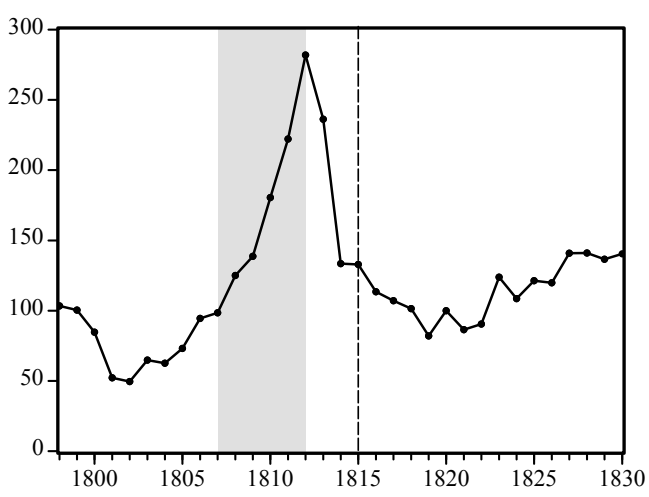

Pepper relative to textiles

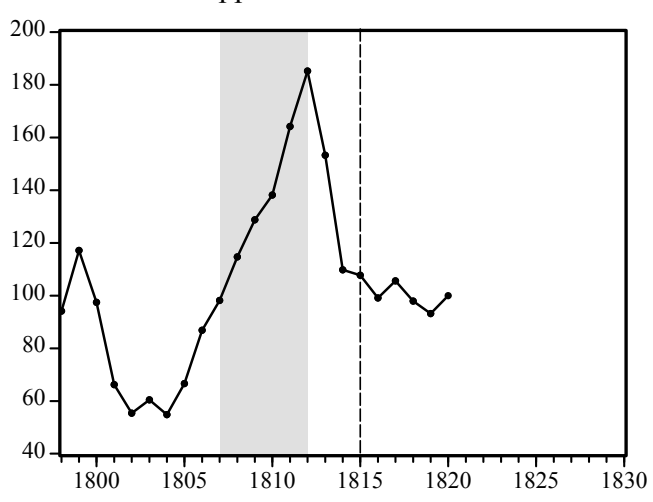

Iron relative to wheat

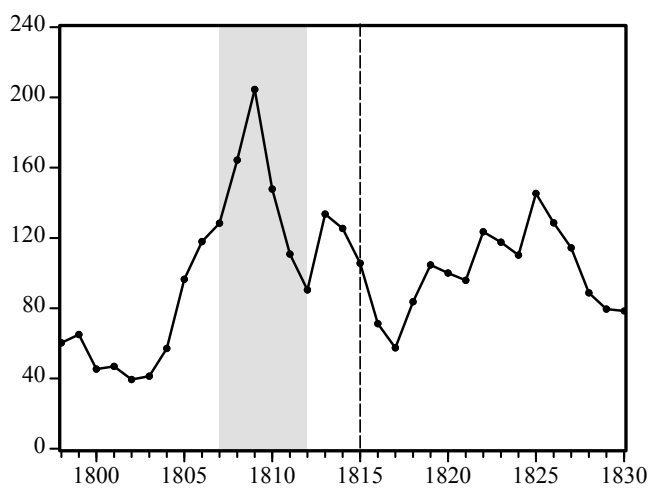

Cotton relative to textiles

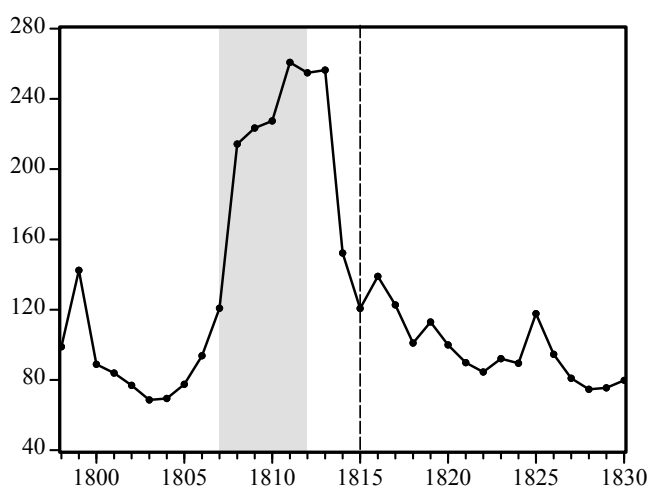

Coffee relative to textiles

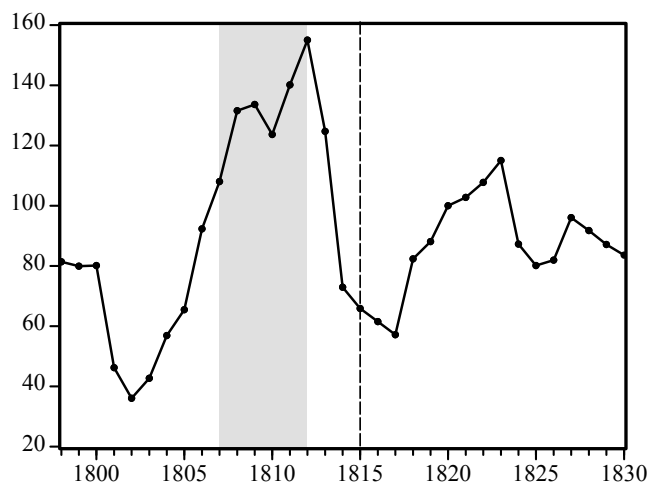

Figure 4. Relative prices in France, 1798-1830 (1820=100)

Source: see Appendix 1. 

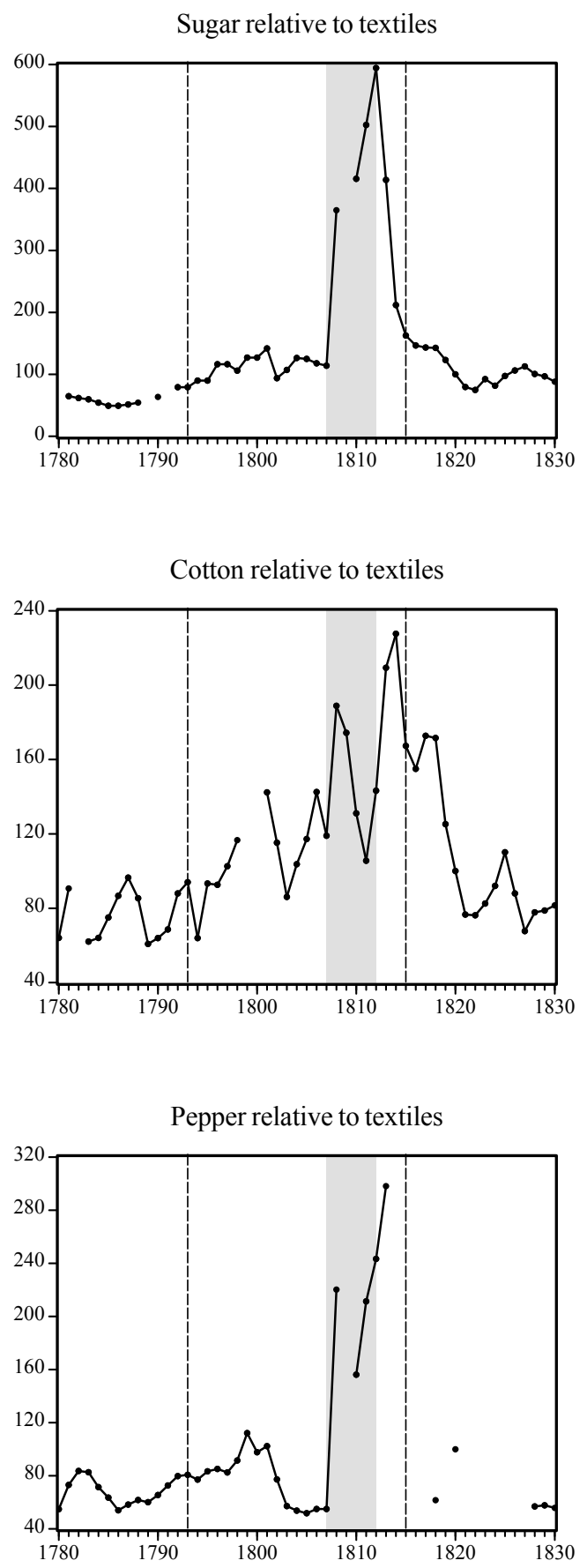

Figure 5. Relative prices in Holland, 1780-1830 (1820=100)

Source: see Appendix 1. 

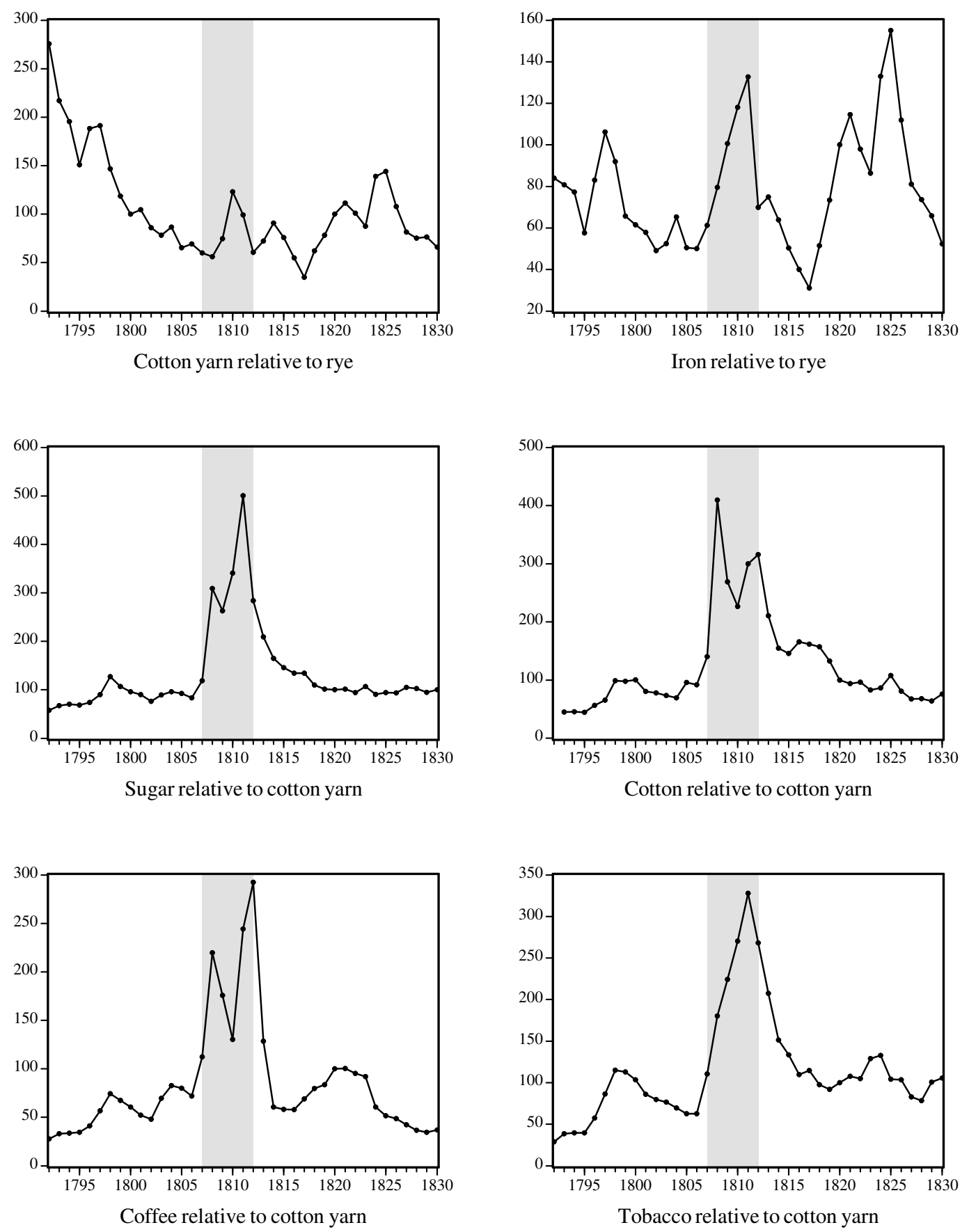

Figure 6. Relative prices in Germany, 1792-1830 (1820=100)

Source: see Appendix 1. 
Textiles relative to iron
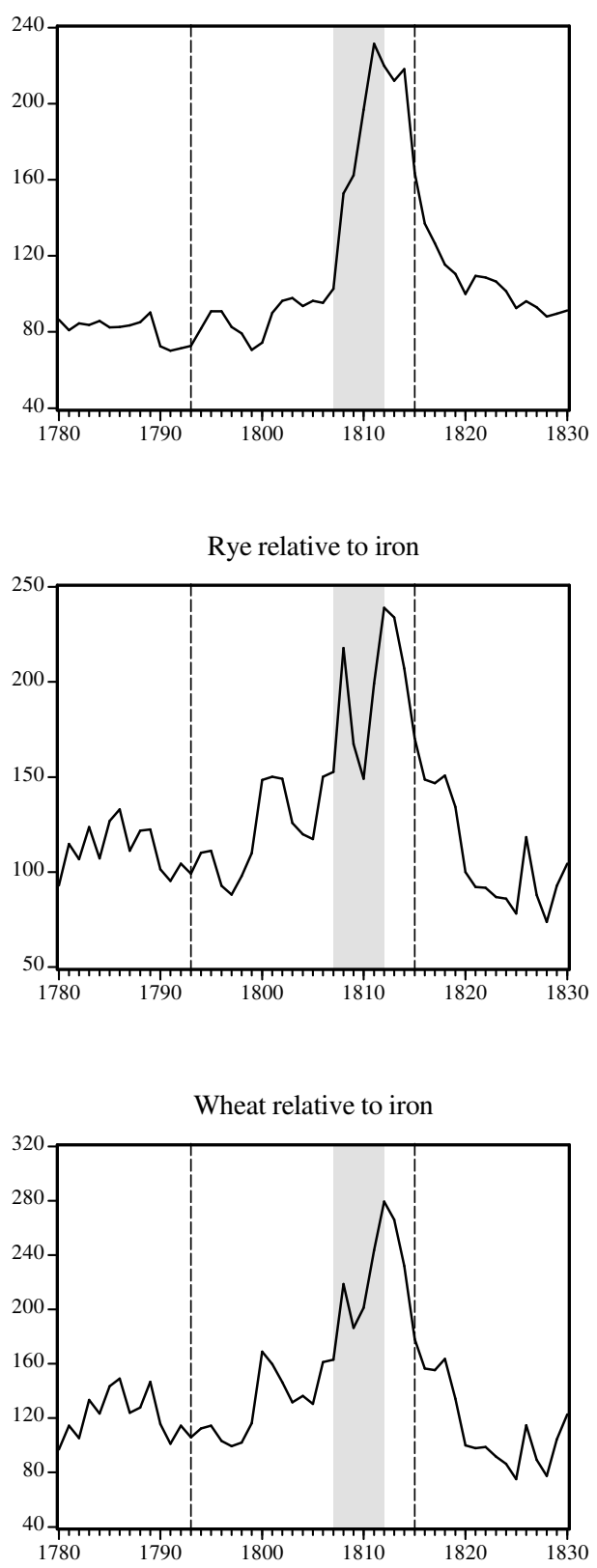

Figure 7. Relative prices in Sweden, 1780-1830 (1820=100)

Source: see Appendix 1. 
Textiles relative to cotton

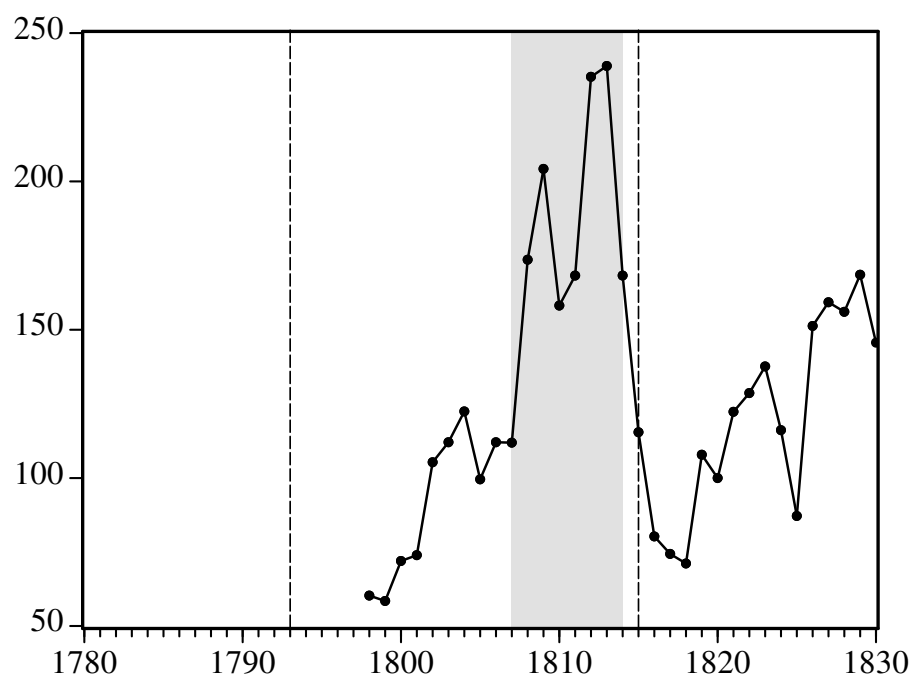

Wine relative to cotton

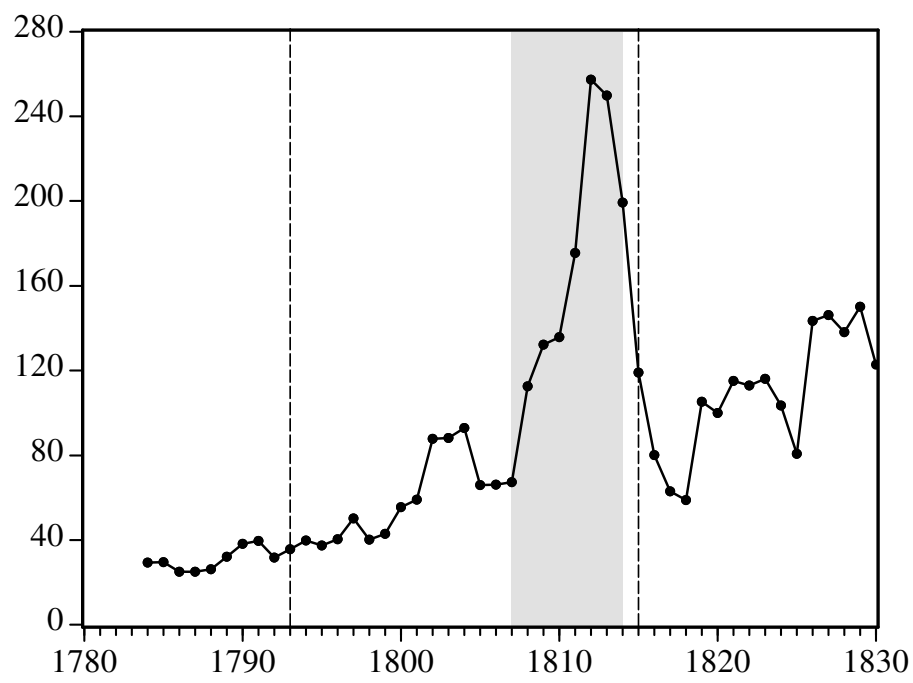

Figure 8. Relative prices in the U.S., 1780-1830 $(1820=100)$

Source: see Appendix 1. 

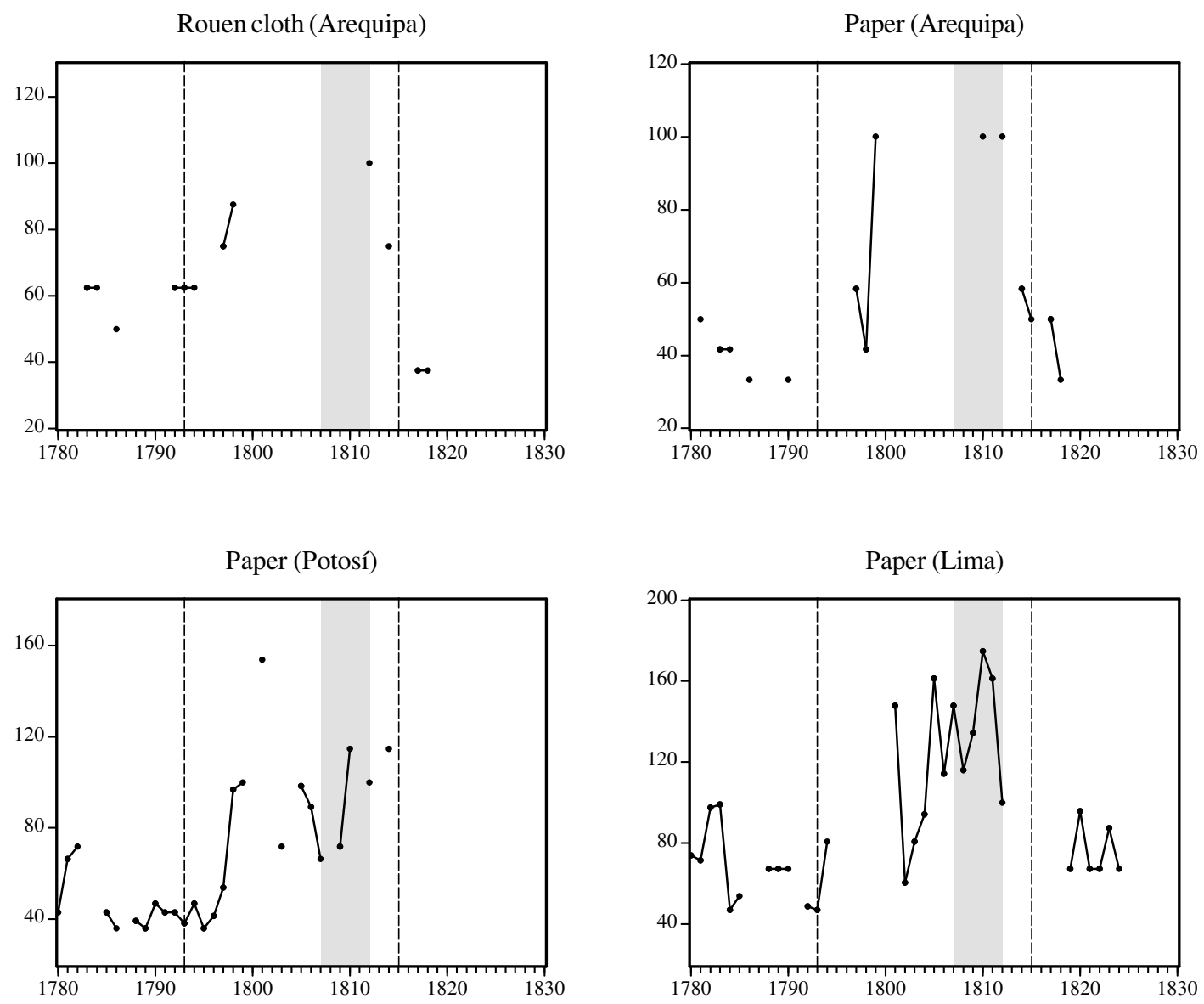

Figure 9. Peruvian silver prices 1780-1830 (1812=100)

Source: see Appendix 1. 


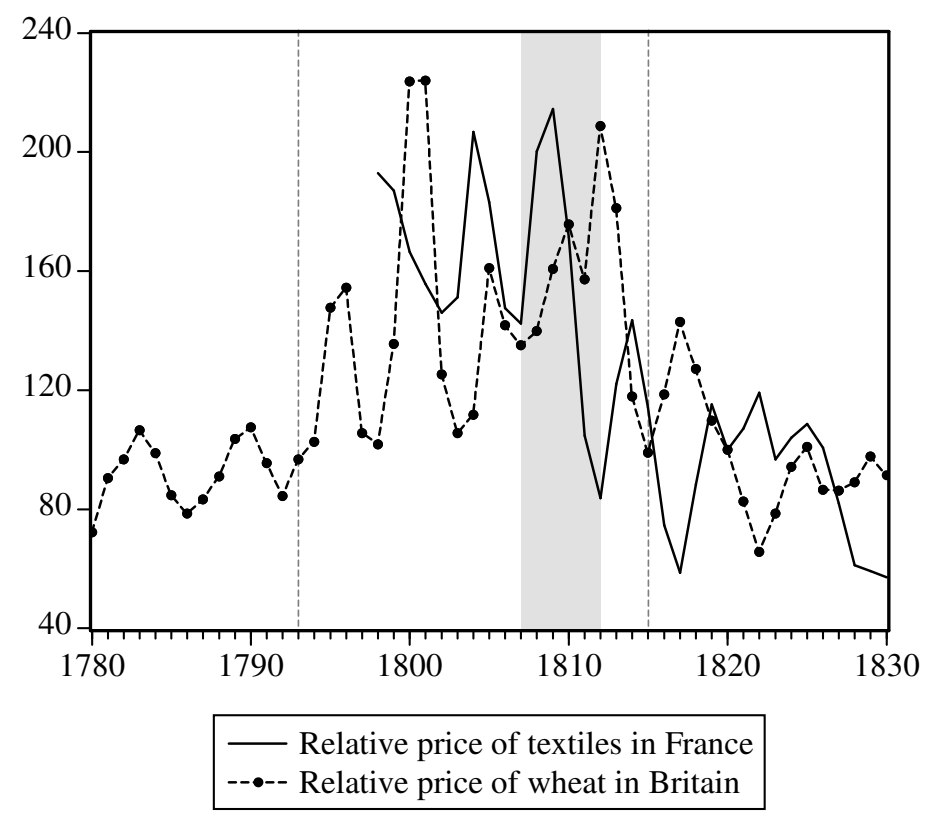

Figure 10. Relative wheat/textile prices in Britain and France, 1780-1830 Source: see Appendix 1. 

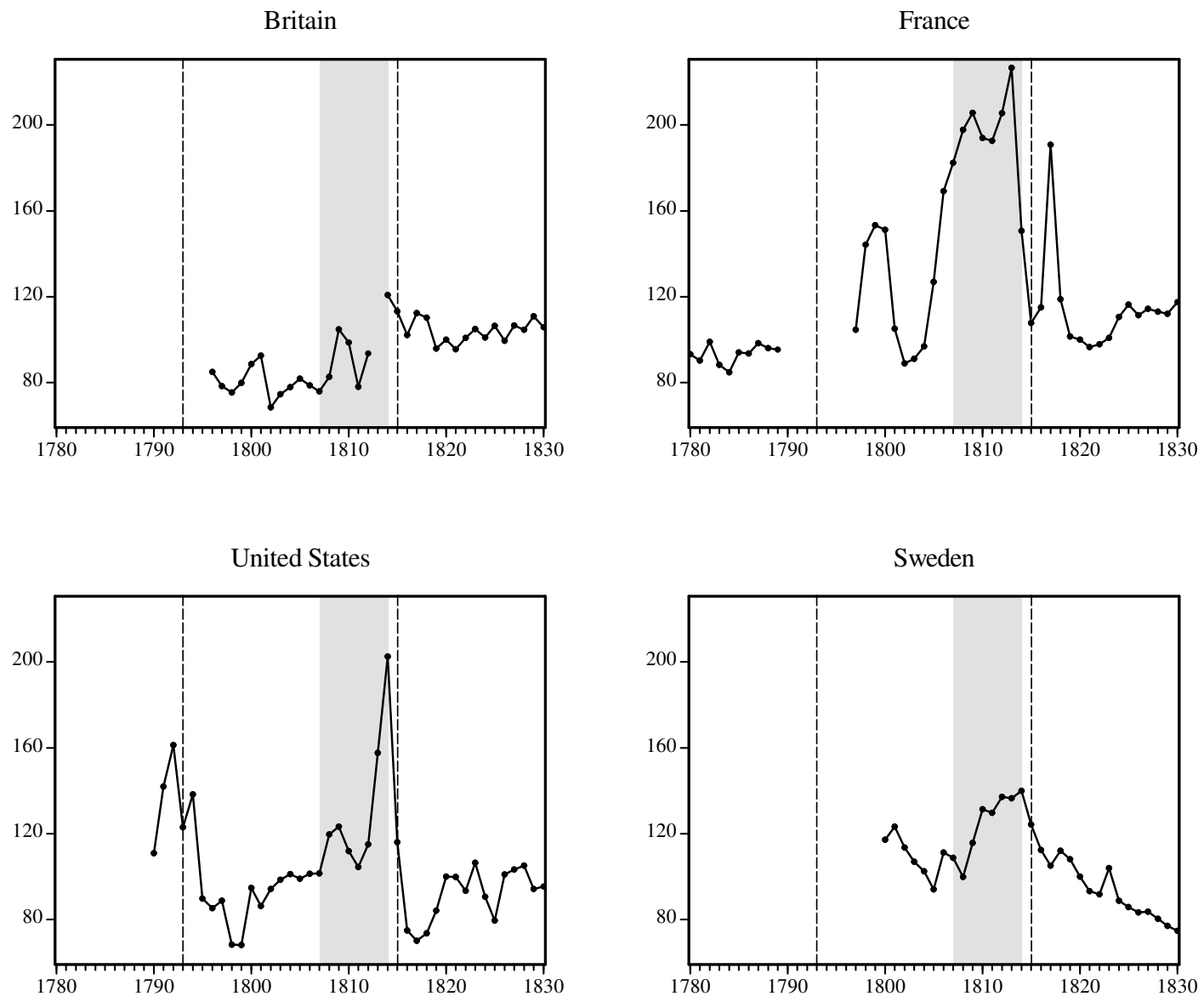

Figure 11. Price of imports relative to exports, 1780-1830 $(1820=100)$

Source: see Appendix 1. 


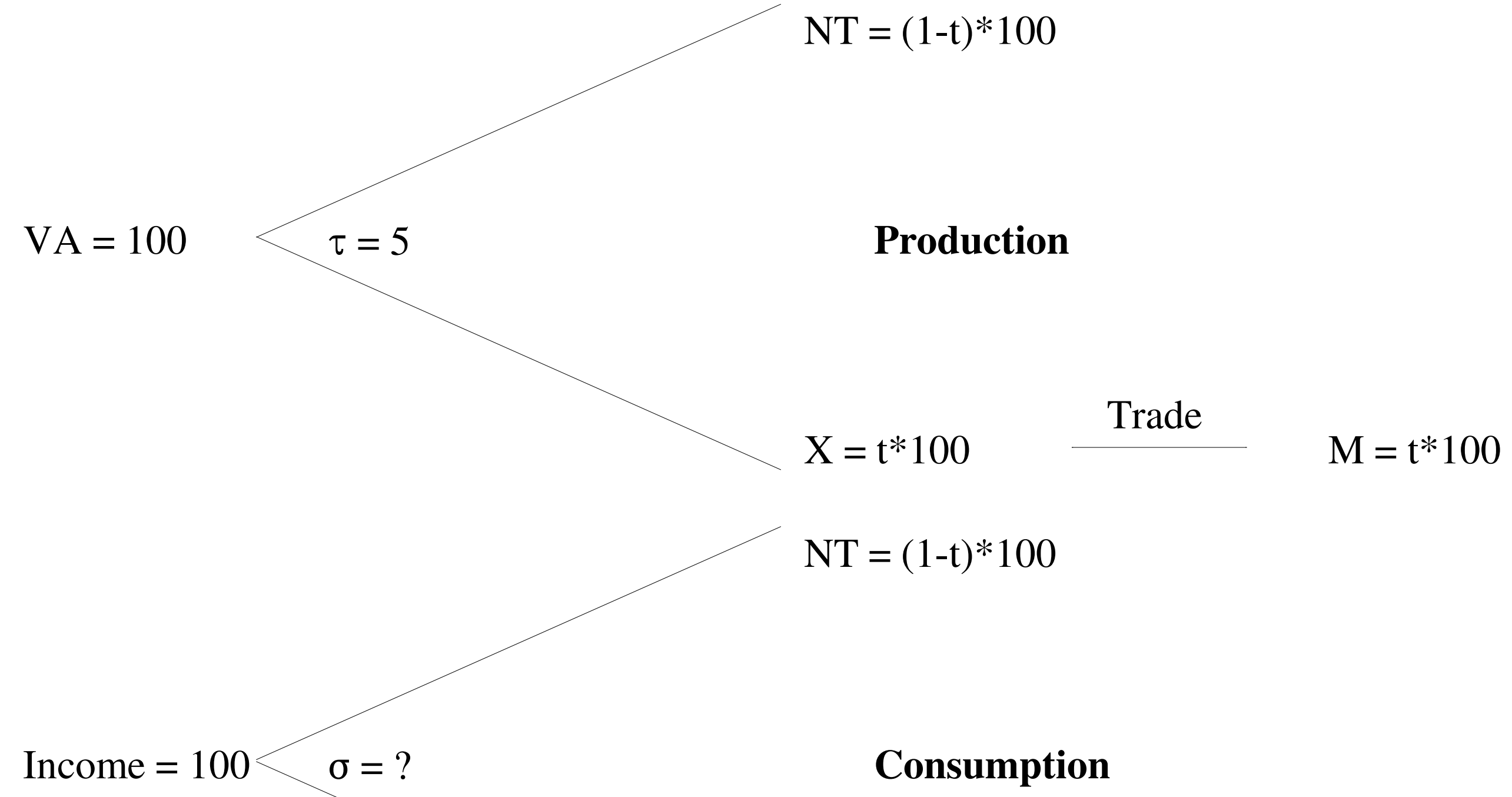

Consumption

$$
\mathrm{M}=\mathrm{t}^{*} 100
$$

Figure 12. Calibrating the CGE model 


\section{Appendix 1. Data sources}

\section{$\underline{1 .}$ Trade volumes and terms of trade}

Britain. Imports: Imlah (1958), Table 8, pp. 94-98. Exports: 1780-1821, Cuenca Esteban (1997), Appendix Table 1, p. 901, spliced with Imlah's data for 1821-30.

France: 1780-1820: data underlying Cuenca Esteban (2004), graciously made available by the author. The price indices for 1716-86 rest on 11 price series with constant weights (Cuenca Esteban 2004 , p. 65). 1820-1830: Lévy-Leboyer and Bourguignon (1990), Tables A-III, AIV.

Sweden: Schön (1984).

United States: North (1966), pp. 221, 228-9, 233-4, 240-3.

\section{Commodity prices}

$\underline{\text { Britain }}$

Beveridge (1939) (pepper: white pepper, Lord Steward's Department, p. 431; sugar: refined sugar, Lord Steward's Department, p. 431; tea: green tea, Lord Steward's Department, folding sheet II; textiles: cloth, Eton College, p. 147).

Mitchell (1988) (raw cotton: 1782-1820, mid-point of range, West Indies, Surinam and Berbice, p. 759, spliced to average price of upland/middling American, p. 760 (1820-1830); wheat, p. 756).

Gayer et al. (1953), microfilm supplement (timber).

\section{$\underline{\text { France }}$}

Annuaire Statistique de la France, 1966, p. 406 (1790 and 1820-1830: coffee, iron, raw cotton, sugar, wheat).

Chabert (1945) (1798-1820: coffee, p. 135; iron, moyenne, p. 200; pepper, p. 140; raw cotton, pernambouc, p. 161; sugar, p. 129; textiles, general index, p. 195 (to 1809); wheat, p. 79).

Hauser (1936) (sugar, Paris, 1780-91, p. 142; wheat, 1780-98, Château-Gontier, p. 209).

Lévy-Leboyer (1970) (textiles, 1809-30, pp. 108-9).

The Netherlands

1780-1800 (sugar, textiles): Jan Luiten van Zanden (n.d.), “The prices of the most important consumer goods, and indices of wages and the cost of living in the western part of the Netherlands, 1450-1800," data supplied by Jan de Vries, Jan Pieter Smits and Arthur van Riel, available online at the International Institute of Social History's Prices and Wages website, at http://www.iisg.nl/hpw/data.html. 
1800-1830 (raw cotton, sugar, textiles, wheat): Arthur van Riel (n.d.), "Prices of consumer and producer goods, 1800-1913," available online at the International Institute of Social History's Prices and Wages website, at http://www.iisg.nl/hpw/data.html.

Posthumus (1946) (pepper, p. 177; Surinam cotton, 1780-1801, p. 286; wheat, Königsberg, p. $3)$.

\section{$\underline{\text { Peru }}$}

Brown (1990) (Rouen cloth and paper, Arequipa, Table 7.1, pp. 178-9).

Tandeter and Wachtel (1990) (paper, Potosí, Table 8.1, pp. 205-6).

These data are also available online at Richard Garner's Latin American Economic History Data Bank, at http://mansell.stucen.gatech.edu/rlg7/latamdata/index.html, from which the Lima paper prices were also taken. The original source for the latter is given as Pablo Macera et al., Los Precios de Peru: Siglo xvi-xix, Fuentes (Lima: Banco Central del Reserva) 1992, Volume 1, pp. 119-62.

\section{$\underline{\text { Sweden }}$}

Jörberg (1972) (bar iron, pp. 706-7; coarse cloth, pp. 683-4; rye and wheat, pp. 633-4).

\section{$\underline{\text { United States }}$}

Cole (1938) (raw cotton, Philadelphia 1784-1796, Statistical Supplement, pp. 78-110, Charleston 1796-1830, main volume, p. 154; sugar, Muscovado, Philadelphia 1784-1800, pp. 77-122). Where necessary, shillings were converted into dollars at the rate of 7.5 shillings to the dollar (main volume, p. 37).

U.S. Department of Commerce (1975) (sugar, 1800-1830, series E125, p. 209; wine, series E110, p. 205).

Warren and Pearson (1933) (textiles, p. 25).

\section{Germany}

Jacobs and Richter (1935), pp. 74 ff. is the source for all the German prices used in the paper. 